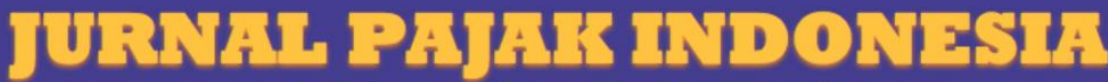

( Indonesian Tax Journal)

www.jurnal.stan.ac.id/index.php/JPI

\section{PELAKSANAAN REKONSILIASI TRANSAKSI \\ PADA MODUL PENERIMAAN NEGARA GENERASI KEDUA}

\author{
Santorry \\ Joko Sumantri \\ Vika Dawin Ni'ma
}

Politeknik Keuangan Negara STAN

santorry@pknstan.ac.id

\section{INFORMASI ARTIKEL}

Diterima Pertama

19-12-2017

Dinyatakan Diterima

19-01-2018

KATA KUNCI: rekonsiliasi match, CA only, SA only, failed.

\section{ABSTRACT}

Transaction reconsiliation through the reconciliation portal generates 4 types of data criteria, That are match, CA Only, SA Only, and failed. Match indicates that the data of state revenue transactions that have been submitted by the bank/post perception in accordance with data recorded on the settlement system. CA Only indicates that the transactions of state revenue and whose money which have been recorded in the Bank/Post of Perception. SA Only indicates that the transaction of state revenue which recorded in the Settlement System, but there is not in the state revenue data that has been submitted by the bank / post perception. Failed indicates that there are transaction data submitted by bank / post perception is invalid. The results of the study have found that the transaction reconsiliation for the period 2015 until quarter 1 of 2017 shows the settled data is greater than the unsettled data. Data settled includes data match, while unsettled data include CA Only, SA Only, and failed data. The largest amount of unsettled data is SA Only, while the smallest amount of unsettled data is failed.

Rekonsiliasi transaksi melalui portal rekonsiliasi menghasilkan 4 jenis kriteria data, yaitu match, CA Only, SA Only, dan failed. Match menunjukkan bahwa data transaksi penerimaan negara yang telah disampaikan oleh bank/pos persepsi sesuai dengan data yang tercatat pada sistem settlement. CA Only menunjukkan bahwa penerimaan negara yang catatan transaksi dan uangnya berada di Bank/Pos Persepsi. SA Only menunjukkan bahwa transaksi penerimaan negara yang tercatat pada Sistem Settlement, namun tidak terdapat pada data penerimaan negara yang telah disampaikan oleh bank/pos persepsi. Failed menunjukkan bahwa terdapat data transaksi yang disampaikan oleh bank/pos persepsi tidak valid. Berdasarkan hasil penelitian ditemukan bahwa rekonsiliasi transaksi periode tahun 2015 s.d triwulan 1 tahun 2017 menunjukkan data settled lebih besar dari data unsettled. Data settled meliputi data match, sedangkan data unsettled meliputi data CA Only, SA Only, dan failed. Jumlah data unsettled terbesar adalah SA Only, sedangkan jumlah data unsettled terkecil adalah failed. 


\section{PENDAHULUAN}

\subsection{Latar Belakang}

Berdasarkan Undang-Undang Nomor 1 Tahun 2004 tentang Perbendaharaan Negara, khususnya Pasal 7 ayat (2) diatur bahwa salah satu wewenang Menteri Keuangan selaku Bendahara Umum Negara adalah menetapkan sistem penerimaan negara. Sistem penerimaan negara ditetapkan guna menjamin efektivitas, efisiensi, akuntabilitas, dan transparansi dalam pengelolaan setiap penerimaan Negara.

Modul Penerimaan Negara (MPN) merupakan sistem penerimaan negara yang dikembangkan oleh Ditjen Perbendaharaan (DJPB). MPN adalah upaya modernisasi pengelolaan perbendaharaan negara. MPN memuat serangkaian prosedur mulai dari penerimaan, penyetoran, pengumpulan data, pencatatan, pengikhtisaran, sampai dengan pelaporan yang berhubungan dengan penerimaan negara. MPN mengintegrasikan tiga sistem penerimaan, yaitu sistem Monitoring Pelaporan Pembayaran Pajak (MP3) oleh Direktorat Jenderal Pajak (DJP), sistem Electronic Data Interchange (EDI) oleh Direktorat Jenderal Bea dan Cukai (DJBC), serta sistem Sistem Penerimaan Negara (SISPEN) oleh Direktorat Jenderal Anggaran (DJA).

MPN berlaku efektif mulai 1 Januari 2007 yang kemudian dikenal dengan sebutan MPN Generasi 1 (MPN G1). MPN G1 berhasil dikembangkan dengan mengurangi kendala-kendala yang ada pada sistem MP3, EDI, dan SISPEN. Salah satunya adalah penerbitan Nomor Transaksi Penerimaan Negara (NTPN) sehingga Wajib Pajak/Wajib Bayar/Wajib Setor (WP/WB/WS) mendapatkan nomor tanda bukti pembayaran/penyetoran ke Kas Negara yang sah. Namun, dalam perkembangannya MPN G1 masih memiliki beberapa permasalahan seperti WP/WB/WS belum terlayani dengan baik serta beberapa transaksi pada MPN G1 masih diragukan keakuratan datanya.

Berdasarkan hasil audit Badan Pemeriksa Keuangan (BPK) Tahun 2009 dan 2010, BPK menyebutkan bahwa data transaksi penerimaan negara yang dilakukan melalui sistem MPN tidak dapat diyakini kebenarannya. Selanjutnya, BPK mengeluarkan opini disclaimer atau tidak menyatakan pendapat atas data transaksi tersebut. Opini ini didasarkan atas tidak dapat dijelaskannya transaksitransaksi hasil rekonsiliasi sistem MPN seperti transaksi kategori reversal, tidak diakui, partial match, MPN unmatch, dan LKP unmatch yang masuk dalam kategori data unreconcilled. Konsekuensi atas opini audit BPK tersebut adalah perlunya penyempurnaan terhadap administrasi setoran Penerimaan Negara sehingga dikembangkanlah sistem MPN generasi baru yang dikenal dengan sebutan MPN Generasi Kedua (MPN G2).

MPN G2 secara bertahap mulai diterapkan melalui bank/pos persepsi sejak bulan Februari 2014. Sistem MPN G2 dikembangkan dengan konsep penerapan sistem electronic billing (e-billing system). Sistem ini mengintegrasikan sistem penerimaan negara dengan menggunakan single database yang ditatausahakan secara terpusat melalui unit khusus di DJPB.

Sistem MPN G2 merupakan upaya optimalisasi pemanfaatan teknologi informasi melalui sistem pembayaran yang lebih modern (transaksi elektronik). Sistem ini sejalan dengan Undang-Undang Informasi dan Transaksi Elektronik (ITE) Nomor 11 Tahun 2008 yaitu informasi elektronik dan/atau dokumen elektronik dan/atau hasil cetaknya merupakan alat bukti hukum yang sah. Hal ini menyebabkan pembayaran penerimaan negara dapat dilakukan kapanpun dalam 24 jam serta cara pembayarannya (payment channel) diperluas. Selain itu, upaya optimalisasi pemanfaatan teknologi informasi dimaksudkan untuk mengurangi intervensi manusia.

Kantor Pelayanan Perbendaharaan Negara (KPPN) Khusus Penerimaan merupakan salah satu instansi vertikal Direktorat Jenderal Perbendaharaan dan bertanggung jawab kepada Direktorat Pengelolaan Kas Negara (Dit. PKN). Selain melaksanakan penerimaan, pengelolaan, penatausahaan, dan pelaporan penerimaan negara, KPPN Khusus Penerimaan juga melaksanakan rekonsiliasi penerimaan negara berdasarkan peraturan perundang-undangan.

Berdasarkan Peraturan Menteri Keuangan Nomor 32/PMK.05/2014 tentang Sistem Penerimaan Negara Secara Elektronik, diatur bahwa untuk menjamin validitas dan akurasi data Penerimaan Negara, KPPN Khusus Penerimaan melakukan rekonsiliasi penerimaan negara. Salah satunya adalah rekonsiliasi transaksi penerimaan negara. Namun, pada kenyataannya efektivitas rekonsiliasi transaksi pada MPN G2 masih dipertanyakan. Hal tersebut terutama dikaitkan dengan masih sering ditemukannya permasalahan dalam rekonsiliasi transaksi pada MPN G2. Rekonsiliasi transaksi pada MPN G2 diindikasikan masih menghasilkan ketidaksesuaian data yaitu CA only dan settlement only.

Mengingat pentingnya rekonsiliasi transaksi MPN G2 di KPPN Khusus Penerimaan untuk menjamin validitas dan akurasi data sehingga menghasilkan laporan penerimaan negara yang kredibel, maka penulis tertarik mengkaji lebih mendalam mengenai rekonsiliasi transaksi pada MPN G2.

\subsection{Tujuan Penulisan}

Tujuan yang ingin dicapai oleh penulis dalam penyusunan tulisan ini adalah:

a. Mengidentifikasi hasil rekonsiliasi transaksi Modul Penerimaan Negara Generasi Kedua (MPN G2).

b. Menganalisis permasalahan yang terjadi dalam pelaksanaan rekonsiliasi transaksi pada MPN G2.

Dengan tujuan penulisan tersebut, diharapkan dapat memberikan manfaat bagi KPPN Khusus Penerimaan dalam menghasilkan laporan penerimaan negara yang kredibel dan akuntabel.

\subsection{Ruang Lingkup dan Pembatasan Masalah}

Penulis membatasi ruang lingkup pembahasan hanya pada pelaksanaan rekonsiliasi transaksi pada MPN G2, identifikasi hasil rekonsiliasi transaksi dan 
upaya minimalisasi permasalahan yang terjadi pada pelaksanaan rekonsiliasi transaksi MPN G2.

\section{METODE PENELITIAN}

Metode yang digunakan penulis adalah metode deskriptif kualitatif dengan dua pendekatan, yaitu :

a. Metode Studi Kepustakaan (Library Research) Metode pengumpulan data dengan melakukan studi penelaahan terhadap buku teks, peraturan perundang-undangan yang berlaku, standar yang telah ditetapkan, artikel yang diterbitkan dalam media cetak maupun elektronik, serta literatur lain yang memiliki keterkaitan dengan objek penelitian. Studi kepustakaan dilakukan untuk mengumpulkan data pendukung atas kebenaran praktik rekonsiliasi transaksi serta informasi landasan teori pelaksanaan rekonsiliasi transaksi MPN G2.

b. Metode Studi Lapangan (Field Research)

Metode pengumpulan data secara langsung ke lapangan dengan melakukan pengamatan untuk memperoleh informasi mengenai praktik atas teori proses rekonsiliasi transaksi MPN G2 secara nyata. Informasi tersebut meliputi praktik pelaksanaan rekonsiliasi transaksi MPN G2, data hasil rekonsiliasi transaksi MPN G2, dan langkahlangkah penyelesaian permasalahan terkait rekonsiliasi transaksi pada MPN G2. Studi lapangan pada KPPN Khusus Penerimaan dilakukan melalui observasi dan wawancara.

1) Observasi

Observasi dilakukan dengan pengamatan langsung ke KPPN Khusus Penerimaan. Dalam pengamatan ini, diajukan permintaan sampel (sebagian populasi) data pendukung hipotesis serta sumber data dan fakta.

2) Wawancara

Wawancara ditujukan kepada narasumber yang dapat memberikan informasi dan/atau memiliki tanggung jawab dalam pelaksanaan rekonsiliasi transaksi MPN G2. Wawancara dilakukan dengan memberikan pertanyaan mengenai praktik rekonsiliasi transaksi yang direkam dan dicatat.

\section{REKONSILIASI TRANSAKSI PERIODE TAHUN 2015 S.D. TRIWULAN 1 TAHUN 2017}

\subsection{Modul Penerimaan Negara Generasi Kedua}

Modul Penerimaan Negara (MPN) merupakan sistem terintegrasi antara Kementerian Keuangan dan sistem bank/pos persepsi dalam rangka penatausahaan dan pengelolaan penerimaan negara. MPN mulai diimplementasikan tahun 2007 dan telah mengalami beberapa kali penyempurnaan.

Pada MPN Generasi I (MPN-G1) masih ditemukan transaksi yang memerlukan tindak lanjut/klarifikasi sebelum diakui sebagai data realisasi penerimaan negara dalam Laporan Keuangan Pemerintah Pusat (LKPP), meliputi transaksi reversal, tidak diakui, partial match, MPN unmatch, dan LKP unmatch.

Hal inilah yang menyebabkan hasil audit BPK tahun 2009 dan 2010 terhadap data transaksi penerimaan Negara melalui sistem MPN (dalam hal ini MPN G1) tidak dapat diyakini kewajarannya (disclaimer).

Konsekuensi atas opini audit BPK adalah timbulnya komitmen pemerintah kepada BPK berupa perlunya penyempurnaan administrasi setoran Penerimaan Negara melalui sistem MPN guna peningkatan kualitas dan akuntabilitas data transaksi Penerimaan Negara yang dicatat melalui sistem MPN, terutama atas hasil penyempurnaan proses rekonsiliasi sistem MPN.

Penyempurnaan administrasi setoran Penerimaan Negara melalui sistem MPN adalah pelaksanaan klarifikasi secara bulanan atas data transaksi hasil rekonsiliasi kategori unmatch data dan mengembangkan sistem MPN G2 berbasis otomasi sebagai sistem MPN generasi baru.

Penyempurnaan atas MPN-G1 selain sistem teknologi informasinya, juga perubahan mekanisme penyetoran oleh wajib pajak/wajib bayar/ wajib setor (WP/ WS/WB), yaitu dari manual billing system menjadi electronic billing system dan fleksibilitas dalam pemilihan kanal layanan penyetoran penerimaan Negara pada bank/pos persepsi (teller/ ATM/internet banking/EDC).

Dalam rangka penyempurnaan sistem penerimaan negara, telah ditetapkan Peraturan Menteri Keuangan Nomor 32/PMK.05/2014 Tentang Sistem Penerimaan Negara Secara Elektronik. PMK ini merupakan dasar hukum implementasi Sistem Penerimaan Negara Secara Elektronik melalui Modul Penerimaan Negara Generasi Kedua (MPN-G2). Melalui MPN-G2 diharapkan dapat meningkatkan akuntabilitas penerimaan negara.

a. Pertama, dari manual billing system menjadi electronic billing system

Pada MPN-G1, WB/WS/WP sebelum melakukan penyetoran terlebih dahulu mengisi formulir surat setoran untuk diserahkan kepada teller bank/pos persepsi. Selanjutnya, petugas teller melakukan entry ke sistem MPN. Pada MPN-G2, pembayaran didahului dengan pembuatan/create billing oleh WB/WS/WP melalui portal unit pemilik tagihan (biller) untuk mendapat kode billing. Dengan kode billing, WB/WS/WP melakukan transaksi pembayaran ke kanal layanan bank/pos persepsi (teller/ATM/ internet banking/EDC). Peran teller hanya melakukan entry kode billing, sedangkan seluruh data transaksi sepenuhnya menjadi tanggung jawab WP/WS/WB.

b. Kedua, dari single channel menjadi multi channel

Pada MPN-G1, layanan penyetoran hanya melalui petugas teller, sedangkan pada MPN-G2 tersedia beberapa pilihan kanal layanan yaitu loket/teller, ATM, Internet Banking, dan Electronic Data Capture (EDC). MPN-G2 memberikan fleksibilitas bertransaksi karena tidak terikat waktu dan tempat. Penyetoran melalui petugas teller pada MPN-G2 tidak tergantung pada kantor cabang bank/pos persepsi tertentu. Pada MPNG1, kantor cabang bank/pos persepsi yang dapat menerima penyetoran penerimaan negara hanya terbatas pada kantor cabang yang telah ditunjuk sebagai bank/pos persepsi mitra kerja KPPN. Pada 
MPN-G2, penyetoran dapat dilakukan di seluruh unit layanan bank/pos persepsi sepanjang memiliki jaringan online dengan kantor pusatnya.

c. Ketiga, dari decentralized account menjadi centralized account

Pada MPN-G1, pembukaan rekening kas Negara persepsi didasarkan per kantor cabang bank/pos persepsi yang bermitra dengan KPPN. Pada MPN-G2, hanya ada satu rekening pada setiap bank/pos persepsi, sehingga transaksi penerimaan negara pada unit layanan bank/pos persepsi akan tercatat pada satu rekening. Penyederhanaan jumlah rekening lebih mempermudah BUN dalam melakukan pengawasan dan pengendalian atas rekening persepsi.

d. Keempat, dari single currency menjadi multi currency

Pada MPN-G1, transaksi penerimaan negara hanya untuk transaksi dalam mata uang Rupiah, sedangkan untuk transaksi dengan menggunakan mata uang asing dilakukan melalui Bank Indonesia. Dengan MPN-G2 maka seluruh penerimaan negara baik dalam mata uang Rupiah maupun mata uang asing (USD) dapat dilakukan.

e. Kelima, dari pengelolaan layanan dan data transaksi per unit eselon 1 (individual) menjadi bersama dan terkoordinasi.

Hal ini dimaksudkan agar terciptanya kesatuan database dan informasi penerimaan Negara. Dengan adanya kesatuan database dan informasi penerimaan Negara, MPN G2 diharapkan mampu meningkatkan kualitas dan akuntabilitas data transaksi penerimaan Negara.

f. Keenam, dari disclaimer menjadi WTP

Salah satu dari tujuan pelaksanaan sistem MPN adalah meningkatkan akuntabilitas. Dalam hal pencatatan penerimaan negara melalui sistem MPN, tingkat akuntabilitas proses tersebut dapat diukur melalui hasil audit baik secara internal maupun eksternal. Hasil ini menunjukkan tingkat kepercayaan publik atas MPN G2.

\section{Gambar 1}

Proses Bisnis MPN G2

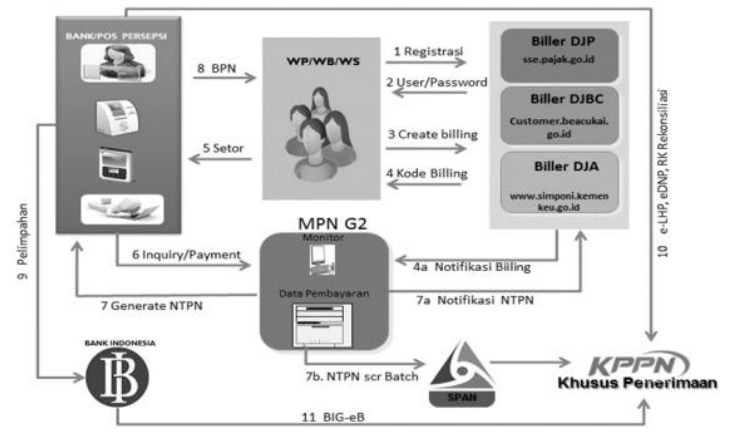

Sumber: Modul MPN G-2

Penjelasan atas gambar proses bisnis MPN G2
1) Wajib
Pajak/Wajib
Bayar/Wajib
Setor

(WP/WB/WS) melakukan registrasi sesuai jenis penerimaan negara yang akan dibayarkan dengan mengakses sistem billing masing-masing biller yaitu biller DJP (sse.pajak.go.id), biller DJBC (customer.beacukai.go.id), atau biller DJA (www.simponi.kemenkeu.go.id) dengan mendaftarkan alamat $e$-mail aktif yang dimiliki.

2) Apabila proses pendaftaran berhasil, WP/WB/WS akan menerima data user ID, Personal Identification Number (PIN)/password, dan link aktivasi akun melalui e-mail yang didaftarkan.

3) WP/WB/WS membuat billing pada biller yang sesuai. Pembuatan billing dilakukan setiap akan melakukan pembayaran kewajiban pajak dan penyetoran PNBP. Pembuatan ID/kode billing ini dimaksudkan untuk mengoneksikan data WP/WB/WS yang akan melakukan pembayaran dengan data registrasi yang telah tersimpan pada saat mendaftar. Kode billing pajak memiliki masa kedaluwarsa dua hari sedangkan PNBP selama tiga hari. Jika dalam jangka waktu tersebut belum dilakukan pembayaran, maka ID/kode billing tidak dapat digunakan lagi dan wajib pajak/setor harus melakukan proses ulang pembuatan kode billing pajak/PNBP. WP/WB/WS bertanggung jawab atas kebenaran dan kelengkapan data pembayaran berkenaan.

4) Setelah proses pembuatan billing selesai, biller akan mengirimkan kode billing kepada WP/WB/WS untuk digunakan sebagai kode pembayaran pada channel pembayaran yang digunakan.

5) 4a) Pada saat yang bersamaan, biller juga mengirimkan notifikasi billing ke sistem MPN G2.

6) WP/WB/WS melakukan pembayaran ke bank/pos persepsi melalui channel pembayaran yang tersedia dengan menggunakan kode billing yang telah didapat. Sementara itu kode billing yang telah di-input saat pembayaran dikirim ke sistem MPN G2 melalui MoF switcher system (switcher). Switcher adalah sistem yang digunakan untuk setelmen dan rekonsiliasi data transaksi penerimaan negara yang ditempatkan diantara pengelola MPN G2 (Ditjen Perbendaharaan) dengan collecting agent. Sistem MPN G2 memproses kode billing untuk memverifikasi data identitas pembayar, jenis pembayaran (akun), dan jumlah tagihan.

7) Data konfirmasi pembayaran selanjutnya dikirimkan melalui switcher ke media pembayaran yang tersedia pada bank/pos persepsi untuk ditayangkan. Sistem bank/pos persepsi akan mengkredit dana ke rekening penerimaan pada bank/pos persepsi.

8) Selanjutnya sistem pada bank/pos persepsi memberi Nomor Transaksi Bank (NTB) atau Nomor Transaksi Pos (NTP) beserta tanggal setor, kode bank dan flag data yang dikirimkan ke sistem MPN G2 melalui switcher sebagai dasar pembuatan NTPN. NTB adalah nomor bukti transaksi penyetoran penerimaan negara yang diterbitkan oleh bank sebagai Bank Persepsi. NTP adalah nomor bukti transaksi penyetoran penerimaan negara yang diterbitkan oleh kantor pos sebagai pos persepsi.

9) 7a) Selanjutnya, pada sistem MPN G2 dihasilkan flag data dengan status paid (dibayar), tanggal 
pembayaran, jumlah setoran, NTB/NTP, kode bank, dan NTPN. Data ini dikirim ke sistem bank/pos persepsi dan biller secara real time melalui switcher untuk direkam. Data yang dikirim ke biller tersebut menandai bahwa status tagihan telah dibayar.

10) 7b) Data transaksi yang telah mendapatkan NTPN secara batch/bertahap/scheduled diunggah ke SPAN (Sistem Perbendaharaan Anggaran Negara) oleh sistem MPN G2.

11) Data NTPN yang diterima sistem bank/pos persepsi selanjutnya diproses menjadi Bukti Penerimaan Negara (BPN) yang dapat berupa struk ataupun tersimpan pada internet banking.

12) Bank/pos persepsi melimpahkan penerimaan negara ke Sub Rekening KUN Penerimaan di Bank Indonesia paling lambat pukul 16:30 WIB untuk penerimaan yang diterima bank/pos persepsi pada hari sebelumnya setelah pukul 15:00 WIB sampai dengan pukul 15:00 WIB hari berkenaan.

13) Untuk keperluan rekonsiliasi, bank/pos persepsi berkewajiban untuk mengirimkan Laporan Harian Penerimaan elektronik (e-LHP) yang terdiri dari Daftar Nominatif Penerimaan elektronik (e-DNP), nota debet pelimpahan, dan Rekening Koran Rekonsiliasi kepada KPPN Khusus Penerimaan

14) KPPN Khusus Penerimaan memonitor saldo dan mutasi rekening melalui sarana elektronik BIG-eB yang telah disediakan oleh Bank Indonesia untuk Kementerian Keuangan.

\subsection{Rekonsiliasi Modul Penerimaan Negara Generasi Kedua}

Rekonsiliasi merupakan salah satu proses bisnis penerimaan Negara pada sistem MPN G2. Rekonsiliasi MPN G2 dilaksanakan guna menjamin validitas dan akurasi data Penerimaan Negara. Pelaksanaan rekonsiliasi MPN G2 diatur dalam Peraturan Menteri Keuangan Nomor 32/PMK.05/2014 tentang Sistem Penerimaan Negara Secara Elektronik.

Proses rekonsiliasi pada MPN G2 dimaksudkan untuk memastikan bahwa setoran tersebut sah dan telah diterima di RKUN serta telah tercatat di sistem settlement. KPPN Khusus Penerimaan melakukan 2 jenis rekonsiliasi pada MPN G2, yaitu rekonsiliasi transaksi dan rekonsiliasi kas.

Rekonsiliasi transaksi adalah kegiatan membandingkan data setoran Penerimaan Negara yang diterima oleh Bank/Pos Persepsi dengan data Penerimaan Negara yang tercatat pada sistem settlement. Rekonsiliasi transaksi dilakukan secara harian. Rekonsiliasi transaksi menghasilkan tiga jenis data yaitu kesesuaian data (settled), collecting agent only (CA only), dan settlement only (SA only).

Rekonsiliasi kas adalah kegiatan membandingkan jumlah uang yang dilimpahkan ke sub Rekening KUN penerimaan dengan kewajiban pelimpahan oleh Bank/Pos Persepsi berdasarkan transaksi Penerimaan Negara pada hari kerja berkenaan. (2) Dokumen yang digunakan dalam rekonsiliasi kas meliputi:

1) nota debet dan rekening koran yang diterima dari Bank/Pos Persepsi;
2) nota kredit dan rekening koran sub Rekening KUN penerimaan; dan

3) LHP Elektronik.

Dalam hal jumlah uang yang dilimpahkan oleh Bank/Pos Persepsi lebih besar dari kewajiban pelimpahan pada hari berkenaan, KPPN Khusus Penerimaan melakukan pengembalian atas kelebihan pelimpahan tersebut paling lambat 5 (lima) hari kerja sejak dokumen permintaan pengembalian dimaksud diterima secara lengkap dan benar atau melakukan kompensasi yaitu pengurangan jumlah uang yang harus dilimpahkan ke RKUN pada hari berikutnya sebesar kelebihan pelimpahan.

Dalam hal jumlah uang yang dilimpahkan oleh Bank/Pos Persepsi lebih kecil dari kewajiban pelimpahan pada hari berkenaan, KPPN Khusus Penerimaan memerintahkan Bank/Pos Persepsi melakukan pelimpahan atas kekurangan pelimpahan tersebut. Bank/Pos Persepsi yang melakukan kekurangan pelimpahan akan dikenai sanksi administratif berupa denda. Besaran denda ditetapkan dalam perjanjian kerja sama antara Direktur Jenderal Perbendaharaan selaku Kuasa BUN Pusat dengan Bank/Pos Persepsi.

\subsection{Rekonsiliasi Transaksi Tahun 2015}

Berdasarkan tabel 1, dapat diketahui bahwa jumlah data transaksi yang disetelmen pada Portal Rekonsiliasi MPN G2 dalam mata uang Rupiah selama tahun 2015 adalah sebanyak 9.291.860 transaksi dengan nilai Rp296.626.968.086.186,00. Hasil rekonsiliasi transaksi menunjukkan bahwa selama tahun 2015 tercatat bahwa dari 9.291.860 transaksi tersebut, 8.134.079 transaksi merupakan transaksi yang memiliki kategori jenis data settled (data yang telah sesuai) yaitu data match dengan nilai transaksi sebesar Rp221.567.979.842.423,00.

Hasil rekonsiliasi transaksi selama tahun 2015 juga menunjukkan adanya kategori jenis data unsettled (data yang tidak sesuai), yaitu CA Only, SA Only, dan failed. Selama tahun 2015, tercatat bahwa sebanyak 8.007 transaksi termasuk dalam kategori CA Only yang memiliki nilai transaksi sebesar Rp121.833.359.129,00. Transaksi dengan status SA Only pada tahun 2015 adalah sebanyak 3.640 transaksi dengan nilai transaksi sebesar Rp1.150.097.614.782,00. Hasil transaksi rekonsiliasi juga menunjukkan bahwa selama tahun 2015 sebanyak 1.019 transaksi dengan nilai transaksi sebesar Rp108.486.790.459,00 termasuk dalam kategori transaksi Failed. Selama tahun 2015, masih terdapat selisih antara data setelmen dan data hasil rekonsiliasi, baik pada triwulan I, triwulan II, triwulan III, maupun triwulan IV tahun 2015. 
Tabel 1

Hasil Rekonsiliasi Transaksi Mata Uang IDR 2015

\begin{tabular}{|c|c|c|c|c|}
\hline \multirow{2}{*}{ Triwulan } & \multicolumn{2}{|c|}{ Setelmen } & \multicolumn{2}{|c|}{ Match } \\
\hline & Trx & Nominal & Trx & Nominal \\
\hline 1 & 449.015 & 25.946 .137 .581 .824 & 33.73 & 308.598 .907 .552 \\
\hline 2 & 1.590 .161 & 72.286 .784 .975 .123 & 887.184 & 24.446 .316 .290 .356 \\
\hline 3 & 2.832 .335 & 64.994.946.384.741 & 2.768 .846 & 63.870.996.504.106 \\
\hline 4 & 4.420 .349 & 133.399 .099 .144 .498 & 4.444 .319 & 132.942 .068 .140 .409 \\
\hline \multirow{2}{*}{ Triwulan } & \multicolumn{2}{|c|}{ CA Only } & \multicolumn{2}{|c|}{ SA Only } \\
\hline & Trx & Nominal & Trx & Nominal \\
\hline 1 & 2 & 22.106 .684 & 121 & 105.321.257 \\
\hline 2 & 616 & 2.572 .688 .548 & 1.446 & 558.734 .590 .233 \\
\hline 3 & 717 & 21.935 .067 .967 & 1.387 & 464.011 .074 .106 \\
\hline 4 & 6.672 & 97.303 .495 .930 & 686 & 127.246 .629 .186 \\
\hline \multirow{2}{*}{ Triwulan } & \multicolumn{2}{|c|}{ Failed } & \multicolumn{2}{|r|}{ Total } \\
\hline & Trx & Nominal & Trx & Nominal \\
\hline 1 & 0 & 0 & 33.853 & 308.726 .335 .493 \\
\hline 2 & 128 & 2.941 .908 .120 & 889.246 & 25.007.623.569.137 \\
\hline 3 & 639 & 101.842 .672 .689 & 2.770 .950 & 64.356 .942 .646 .179 \\
\hline 4 & 252 & 3.702 .209 .650 & 4.451 .677 & 133.166 .618 .265 .525 \\
\hline \multirow{2}{*}{ Triwulan } & \multicolumn{2}{|c|}{ Selisih } & & \\
\hline & Trx & Nominal & & \\
\hline 1 & 415.162 & 25.637 .411 .246 .331 & & \\
\hline 2 & 700.915 & 47.279 .161 .405 .986 & & \\
\hline 3 & 61.385 & 638.003 .738 .562 & & \\
\hline 4 & -31.328 & 232.480 .878 .973 & & \\
\hline
\end{tabular}

Sumber: KPPN Khusus Penerimaan, data diolah

Hasil rekonsiliasi transaksi dalam mata uang asing secara triwulanan selama tahun 2015 ditunjukkan dalam tabel 2. Berdasarkan tabel 2, dapat diketahui bahwa jumlah data transaksi yang disetelmen pada portal rekonsiliasi MPN G2 dalam mata uang asing selama tahun 2015 adalah sebanyak 9.760 transaksi dengan nilai US\$3.205.878.589. Hasil rekonsiliasi transaksi menunjukkan bahwa selama tahun 2015 tercatat bahwa dari 9.760 transaksi tersebut, 6.472 transaksi merupakan transaksi yang memiliki kategori jenis data settled (data yang telah sesuai) yaitu data match dengan nilai transaksi sebesar US\$3.024.384.645.

Selama tahun 2015, tercatat bahwa sebanyak 4 transaksi termasuk dalam kategori CA Only yang memiliki nilai transaksi sebesar US\$124.639. Transaksi dengan status SA Only pada tahun 2015 adalah sebanyak 2 transaksi dengan nilai transaksi sebesar US\$3.662. Hasil transaksi rekonsiliasi juga menunjukkan bahwa selama tahun 2015 sebanyak 1 transaksi dengan nilai transaksi sebesar US\$3.661 termasuk dalam kategori transaksi Failed. Selama tahun 2015, masih terdapat selisih antara data setelmen dan data hasil rekonsiliasi yaitu pada triwulan I, triwulan II, dan triwulan III tahun 2015.
Tabel 2

Hasil Rekonsiliasi Transaksi Mata Uang USD 2015

\begin{tabular}{|c|c|c|c|c|}
\hline \multirow{2}{*}{ Triwulan } & \multicolumn{2}{|c|}{ Setelmen } & \multicolumn{2}{|r|}{ Match } \\
\hline & Trx & Nominal & Trx & Nominal \\
\hline 1 & 1.595 & 21.962 .054 & 0 & 0 \\
\hline 2 & 2.32 & 228.094 .690 & 751 & 83.781 .451 \\
\hline 3 & 2.465 & 1.382 .457 .623 & 2.34 & 1.367.238.975 \\
\hline 4 & 3.38 & 1.573.364.223 & 3.38 & 1.573.364.220 \\
\hline \multirow{2}{*}{ Triwulan } & \multicolumn{2}{|c|}{ CA Only } & \multicolumn{2}{|r|}{ SA Only } \\
\hline & Trx & Nominal & Trx & Nominal \\
\hline 1 & 0 & 0 & 0 & 0 \\
\hline 2 & 0 & 0 & 0 & 0 \\
\hline 3 & 3 & 124.637 & 1 & 3.661 \\
\hline 4 & 1 & 2 & 1 & 1 \\
\hline \multirow{2}{*}{ Triwulan } & \multicolumn{2}{|c|}{ Failed } & \multicolumn{2}{|r|}{ Total } \\
\hline & Trx & Nominal & Trx & Nominal \\
\hline 1 & $\underline{0}$ & 0 & 0 & 0 \\
\hline 2 & 0 & 0 & 751 & 83.781 .451 \\
\hline 3 & 1 & 3.661 & 2.35 & 1.367 .367 .273 \\
\hline 4 & 0 & 0 & 3.38 & 1.573 .364 .223 \\
\hline \multirow{2}{*}{ Triwulan } & \multicolumn{2}{|c|}{ Selisih } & & \\
\hline & Trx & Nominal & & \\
\hline 1 & 1.595 & 21.962 .054 & & \\
\hline 2 & 1.569 & 144.313 .240 & & \\
\hline 3 & 118 & 15.090 .350 & & \\
\hline 4 & 0 & 0 & & \\
\hline
\end{tabular}

Sumber: KPPN Khusus Penerimaan, data diolah

\subsection{Rekonsiliasi Transaksi Tahun 2016}

Hasil rekonsiliasi transaksi dalam mata uang Rupiah secara triwulanan selama tahun 2016 ditunjukkan dalam tabel 3. Berdasarkan tabel 3, dapat diketahui bahwa jumlah data transaksi yang disetelmen pada portal rekonsiliasi MPN G2 dalam mata uang Rupiah selama tahun 2016 adalah sebanyak 54.230.601 transaksi dengan nilai sebesar Rp1.346.895.464.941.570,00. Hasil rekonsiliasi transaksi menunjukkan bahwa selama tahun 2016 tercatat bahwa dari 54.230.601 transaksi tersebut, 54.147.659 transaksi merupakan transaksi yang memiliki kategori jenis data settled (data yang telah sesuai) yaitu data match dengan nilai transaksi sebesar Rp221.567.979.842.423,00.

Selama tahun 2016, tercatat bahwa sebanyak 8914 transaksi termasuk dalam kategori CA Only yang memiliki nilai transaksi sebesar Rp315.099.085.328,00. Transaksi dengan status SA Only pada tahun 2016 adalah sebanyak 55.005 transaksi dengan nilai transaksi sebesar Rp1.298.277.903.926,00. Hasil transaksi rekonsiliasi juga menunjukkan bahwa selama tahun 2016 sebanyak 8.099 transaksi dengan nilai transaksi sebesar Rp114.236.142.170,00 termasuk dalam kategori transaksi failed. Selama tahun 2016, masih terdapat selisih antara data setelmen dan data hasil rekonsiliasi, baik pada triwulan I, triwulan II, triwulan III, maupun triwulan IV tahun 2016 
Tabel 3

Hasil Rekonsiliasi Transaksi Mata Uang IDR 2016

\begin{tabular}{|c|c|c|c|c|}
\hline \multirow{2}{*}{ Triwulan } & \multicolumn{2}{|c|}{ Setelmen } & \multicolumn{2}{|c|}{ Match } \\
\hline & Trx & Nominal & Trx & Nominal \\
\hline 1 & 7.106 .772 & 194.402 .879 .337 .233 & 7.105 .114 & 194.242 .244 .906 .049 \\
\hline 2 & 11.001 .822 & 328.356 .401 .978 .274 & 10.980 .680 & 327.571 .457 .761 .325 \\
\hline 3 & 14.256 .602 & 397.157 .353 .425 .053 & 14.247.535 & 397.061 .426 .464 .411 \\
\hline 4 & 21.865 .405 & 426.978 .830 .201 .015 & 21.814 .330 & 426.208 .262 .291 .033 \\
\hline \multirow{2}{*}{ Triwulan } & \multicolumn{2}{|r|}{ CA Only } & \multicolumn{2}{|c|}{ SA Only } \\
\hline & Trx & Nominal & $\operatorname{Trx}$ & Nominal \\
\hline 1 & 674 & 157.481.931.238 & 953 & 13.678.419.828 \\
\hline 2 & 965 & 44.521.172.741 & 17.963 & 725.044.834.597 \\
\hline 3 & 1.541 & 39.230 .752 .955 & 6.972 & 50.615.102.584 \\
\hline 4 & 5.734 & 73.865.228.394 & 29.117 & 508.939 .546 .287 \\
\hline \multirow{2}{*}{ Triwulan } & \multicolumn{2}{|r|}{ Failed } & \multicolumn{2}{|r|}{ Total } \\
\hline & Trx & Nominal & Trx & Nominal \\
\hline 1 & 88 & 4.646.907.331 & 7.106 .741 & 194.413.405.257.115 \\
\hline 2 & 330 & 5.632.192.032 & 10.999 .608 & 328.341 .023 .768 .663 \\
\hline 3 & 43 & 494.751 .062 & 14.256 .048 & 397.151 .272 .319 .950 \\
\hline 4 & 7.638 & 103.462.291.745 & 21.849.181 & 426.791 .067 .065 .714 \\
\hline \multirow{2}{*}{ Triwulan } & \multicolumn{2}{|r|}{ Selisih } & & \\
\hline & Trx & Nominal & & \\
\hline 1 & 31 & -10.525 .919 .882 & & \\
\hline 2 & 2.214 & 15.378.209.611 & & \\
\hline 3 & 554 & 6.081.105.103 & & \\
\hline 4 & 16.224 & 187.763.135.301 & & \\
\hline
\end{tabular}

Sumber: KPPN Khusus Penerimaan, data diolah

Hasil rekonsiliasi transaksi dalam mata uang asing secara triwulanan selama tahun 2016 ditunjukkan dalam tabel 4. Berdasarkan tabel 4, dapat diketahui bahwa jumlah data transaksi yang disetelmen pada portal rekonsiliasi MPN G2 dalam mata uang asing selama tahun 2016 adalah sebanyak 73.217 transaksi dengan nilai US\$5.880.087.250. Hasil rekonsiliasi transaksi menunjukkan bahwa selama tahun 2016 tercatat bahwa 73.154 transaksi merupakan transaksi yang memiliki kategori jenis data settled (data yang telah sesuai) yaitu data match dengan nilai transaksi sebesar US\$5.873.682.015.

Selama tahun 2016, tercatat bahwa sebanyak 11 transaksi termasuk dalam kategori CA Only dengan nilai transaksi sebesar US\$204.108. Transaksi dengan status SA Only pada tahun 2016 adalah sebanyak 18 transaksi dengan nilai transaksi sebesar US\$780.567. Hasil transaksi rekonsiliasi juga menunjukkan bahwa selama tahun 2016 sebanyak 5 transaksi dengan nilai transaksi sebesar US\$3.980.501 termasuk dalam kategori transaksi failed. Selama tahun 2016, masih terdapat selisih antara data setelmen dan data hasil rekonsiliasi yaitu pada triwulan IV tahun 2016.
Tabel 4

Hasil Rekonsiliasi Transaksi Mata Uang USD 2016

\begin{tabular}{|c|c|c|c|c|}
\hline \multirow{2}{*}{ Triwulan } & \multicolumn{2}{|c|}{ Setelmen } & \multicolumn{2}{|c|}{ Match } \\
\hline & Trx & Nominal & Trx & Nominal \\
\hline 1 & 4.077 & 1.124 .192 .473 & 4.075 & 1.124 .191 .365 \\
\hline 2 & 5.55 & 1.503 .776 .547 & 5.545 & 1.503 .351 .485 \\
\hline 3 & 28.269 & 1.333 .206 .626 & 28.268 & 1.333 .205 .426 \\
\hline 4 & 35.321 & 1.918 .911 .604 & 35.266 & 1.912 .933 .739 \\
\hline \multirow{2}{*}{ Triwulan } & \multicolumn{2}{|c|}{ CA Only } & \multicolumn{2}{|c|}{ SA Only } \\
\hline & Trx & Nominal & Trx & Nominal \\
\hline 1 & 0 & 0 & 2 & 1.108 \\
\hline 2 & 1 & 179.202 & 4 & 245.861 \\
\hline 3 & 1 & 1.2 & 0 & 0 \\
\hline 4 & 9 & 23.706 & 12 & 533.599 \\
\hline \multirow{2}{*}{ Triwulan } & \multicolumn{2}{|c|}{ Failed } & \multicolumn{2}{|c|}{ Total } \\
\hline & Trx & Nominal & Trx & Nominal \\
\hline 1 & 0 & 0 & 4.077 & 1.124 .192 .473 \\
\hline 2 & 1 & 228.851 & 5.55 & 1.503 .776 .547 \\
\hline 3 & 0 & 0 & 28.269 & 1.333 .206 .626 \\
\hline 4 & 4 & 3.751 .650 & 35.287 & 1.913 .491 .044 \\
\hline \multirow{2}{*}{ Triwulan } & \multicolumn{2}{|c|}{ Selisih } & & \\
\hline & Trx & Nominal & & \\
\hline 1 & 0 & 0 & & \\
\hline 2 & 0 & 0 & & \\
\hline 3 & 0 & 0 & & \\
\hline 4 & 34 & 5.420 .560 & & \\
\hline
\end{tabular}

Sumber: KPPN Khusus Penerimaan, data diolah

\subsection{Rekonsiliasi Transaksi Tahun 2015}

Hasil rekonsiliasi transaksi dalam mata uang Rupiah selama Triwulan I tahun 2017 ditunjukkan dalam tabel 5. Berdasarkan tabel 5, dapat diketahui bahwa jumlah data transaksi yang disetelmen pada portal rekonsiliasi MPN G2 dalam mata uang Rupiah selama triwulan I tahun 2017 adalah sebanyak 19.240.214 transaksi dengan nilai sebesar Rp302.208.104.958.780,00.

Hasil rekonsiliasi transaksi menunjukkan bahwa selama triwulan I tahun 2017 tercatat bahwa dari 19.240.214 transaksi tersebut, 19.226.131 transaksi merupakan transaksi yang memiliki kategori jenis data settled (data yang telah sesuai) yaitu data match dengan nilai transaksi sebesar Rp302.098.960.056.963,00.

Hasil rekonsiliasi transaksi selama triwulan I tahun 2017 juga menunjukkan adanya kategori jenis data unsettled (data yang tidak sesuai), yaitu CA Only, SA Only, dan failed. Selama triwulan I tahun 2017, tercatat bahwa sebanyak 2.650 transaksi termasuk dalam kategori CA Only yang memiliki nilai transaksi sebesar Rp48.582.987.710,00. Transaksi dengan status SA Only pada triwulan I tahun 2017 adalah sebanyak 10.231 transaksi dengan nilai transaksi sebesar Rp39.651.168.344,00. Hasil transaksi rekonsiliasi juga menunjukkan bahwa selama triwulan I tahun 2017 sebanyak 304 transaksi dengan nilai transaksi sebesar Rp1.757.580,00 termasuk dalam kategori transaksi failed. Selama triwulan I tahun 2017, masih terdapat selisih antara data setelmen dan data hasil rekonsiliasi pada triwulan I tahun 2017. 


\section{Tabel 5}

Hasil Rekonsiliasi Transaksi Mata Uang IDR Triwulan I 2017

\begin{tabular}{|c|c|c|c|c|}
\hline \multirow{2}{*}{ Triwulan } & \multicolumn{2}{|r|}{ Setelmen } & \multicolumn{2}{|r|}{ Match } \\
\hline & Trx & Nominal & Trx & Nominal \\
\hline & 89.199 & 2.929.399.371.977.00 & 12.723 & 127.982 .838 .907 .00 \\
\hline \multirow{2}{*}{ Triwulan } & \multicolumn{2}{|r|}{ CA Only } & \multicolumn{2}{|r|}{ SA Only } \\
\hline & Trx & Nominal & Trx & Nominal \\
\hline & 0 & 0 & 96] & 57.694 .486 .00 \\
\hline \multirow{2}{*}{ Triwule } & \multicolumn{2}{|r|}{ Failed } & \multicolumn{2}{|r|}{ Total } \\
\hline & Trx & Nominal & $\operatorname{Trx}$ & Nominal \\
\hline & 0 & 0 & 12.819 & 128.040 .533 .393 .00 \\
\hline \multirow{2}{*}{ Triwulan } & \multicolumn{2}{|r|}{ Selisih } & & \\
\hline & $\operatorname{Trx}$ & Nominal & & \\
\hline 1 & 76.38 & 2.801 .358 .838 .584 .00 & & \\
\hline
\end{tabular}

Sumber: KPPN Khusus Penerimaan, data diolah

Hasil rekonsiliasi transaksi dalam mata uang asing selama Triwulan I tahun 2017 ditunjukkan dalam tabel 6. Berdasarkan tabel 6, dapat diketahui bahwa jumlah data transaksi yang disetelmen pada portal rekonsiliasi MPN G2 dalam mata uang asing selama triwulan I tahun 2017 adalah sebanyak 33.143 transaksi dengan nilai US\$2.117.214.718. Hasil rekonsiliasi transaksi menunjukkan bahwa selama tahun 2016 tercatat bahwa 33.131 transaksi merupakan transaksi yang memiliki kategori jenis data settled (data yang telah sesuai) yaitu data match dengan nilai transaksi sebesar US\$2.117.126.144.

Selama triwulan I tahun 2017, tercatat bahwa sebanyak 5 transaksi termasuk dalam kategori CA Only dengan nilai transaksi US\$6.866. Transaksi dengan status SA Only pada triwulan I tahun 2017 adalah sebanyak 8 transaksi dengan nilai transaksi sebesar US\$81.743. Selama triwulan I tahun 2017, masih terdapat selisih antara data setelmen dan data hasil rekonsiliasi.

Tabel 6

Hasil Rekonsiliasi Transaksi Mata Uang USD Triwulan I 2017

\begin{tabular}{|c|c|c|c|c|}
\hline \multirow{2}{*}{ Triwulan } & \multicolumn{2}{|c|}{ Setelmen } & \multicolumn{2}{|c|}{ Match } \\
\hline & Trx & Nominal & Trx & Nominal \\
\hline 1 & 33.143 & 2.117.214.718 & 33.131 & 2.117 .126 .144 \\
\hline \multirow{2}{*}{ Triwulan } & \multicolumn{2}{|c|}{ CA Only } & \multicolumn{2}{|c|}{ SA Only } \\
\hline & Trx & Nominal & Trx & Nominal \\
\hline 1 & 5 & 6.866 & 8 & 81.743 \\
\hline \multirow{2}{*}{ Triwulan } & \multicolumn{2}{|c|}{ Failed } & \multicolumn{2}{|c|}{ Total } \\
\hline & Trx & Nominal & Trx & Nominal \\
\hline 1 & & 0 & 33.144 & 2.117 .214 .753 \\
\hline \multirow{2}{*}{ Triwulan } & \multicolumn{2}{|c|}{ Selisih } & & \\
\hline & Trx & Nominal & & \\
\hline 1 & -1 & -35 & & \\
\hline
\end{tabular}

Sumber: KPPN Khusus Penerimaan, data diolah

\section{PEMBAHASAN}

\subsection{Tinjauan Atas Pelaksanaan Rekonsiliasi Transaksi Pada MPN G2}

Pelaksanaan rekonsiliasi transaksi Penerimaan Negara melalui MPN G2 dilakukan oleh seksi rekonsiliasi pada KPPN Khusus Penerimaan. Rekonsiliasi transaksi dilakukan secara harian. Rekonsiliasi transaksi dilakukan secara otomatis dan by sistem melalui Portal Rekonsiliasi.
Sesuai dengan PMK Nomor 32/PMK.05/2014 tentang Sistem Penerimaan Negara Secara Elektronik, Bank/Pos Persepsi melakukan pelimpahan Penerimaan Negara yang diterima oleh Bank/Pos Persepsi baik dalam mata uang Rupiah maupun mata uang asing. Untuk mata uang Rupiah, bank/pos persepsi melakukan pelimpahan Penerimaan Negara yang telah diterimanya setelah pukul 15.00 waktu setempat pada hari kerja sebelumnya sampai dengan pukul 15.00 waktu setempat pada hari kerja berkenaan. Penerimaan Negara tersebut wajib dilimpahkan dari rekening penerimaan dalam mata uang Rupiah dan harus diterima di rekening sub Rekening KUN penerimaan dalam mata uang Rupiah paling lambat pukul 16.30 WIB.

Penerimaan Negara yang diterima oleh Bank Persepsi dalam mata uang asing setelah pukul 15.00 waktu setempat pada hari kerja sebelumnya sampai dengan pukul 15.00 waktu setempat pada hari kerja berkenaan wajib dilimpahkan dari rekening penerimaan dalam mata uang asing dan harus diterima di rekening sub Rekening KUN penerimaan dalam mata uang asing paling lambat pukul 16.30 WIB. Selanjutnya, bank/pos persepsi akan menyampaikan data transaksi berupa LHP Elektronik, DNP Elektronik, dan Rekening Koran ke KPPN Khusus Penerimaan.

Pelaksana seksi rekonsiliasi meneliti laporan data transaksi yang telah disampaikan oleh bank/pos persepsi. Bank/pos persepsi menyampaikan LHP Elektronik yang digunakan sebagai input oleh KPPN Khusus Penerimaan untuk melakukan rekonsiliasi kas pada portal rekonsiliasi. Bank/pos persepsi menyampaikan DNP Elektronik yang digunakan sebagai input oleh KPPN Khusus Penerimaan untuk melakukan rekonsiliasi transaksi pada portal rekonsiliasi.

LHP Elektronik yang merupakan singkatan dari Laporan Hasil Penerimaan Elektronik adalah laporan harian penerimaan Negara yangdibuat oleh Bank/Pos Persepsi dalam bentuk arsip data komputer. LHP Elektronik berisi data Penerimaan Negara yang diterima setelah Pukul 15.00 waktu setempat pada hari kerja sebelumnya sampai dengan Pukul 15.00 waktu setempat hari kerja berkenaan. LHP Elektronik terdiri dari nota debet pelimpahan, daftar nominatif penerimaan, dan rekening Koran.

LHP Elektronik disampaikan melalui portal Kementerian Keuangan. LHP Elektronik disampaikan secara terpisah untuk masing-masing rekening penerimaan. LHP Elektronik disampaikan paling lambat Pukul 09.00 WIB pada hari kerja berikutnya atau waktu lain yang ditetapkan oleh BUN/Direktur Jenderal Perbendaharaan selaku Kuasa BUN Pusat.

LHP Elektronik digunakan sebagai input untuk melakukan rekonsiliasi kas melalui portal rekonsiliasi oleh KPPN Khusus Penerimaan. Rekening Koran disampaikan bank/pos persepsi dalam rangka pelaksanaan rekonsiliasi kas pada KPPN Khusus Penerimaan. Rekening Koran digunakan untuk meneliti pelimpahan.

DNP Elektronik merupakan singkatan dari Daftar Nominatif Penerimaan Elektronik. Bank/pos persepsi mengirimkan DNP Elektronik ke portal Kementerian 
Keuangan pada akhir hari kerja guna keperluan rekonsiliasi transaksi.

Daftar Nominatif Penerimaan mengunakan semicolon sebagai delimeter dengan extention ".txt". Format text file DNP Elektronik adalah kode bank; tanggal transaksi; waktu transaksi; tanggal buku; kode billing; NTB; NTPN; nilai nominal; mata uang; nomor sakti. Contoh DNP Elektronik ditunjukkan pada gambar 3.

Gambar 3

Contoh DNP Elektronik

D. Elektronlik

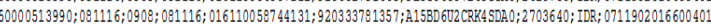

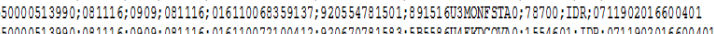

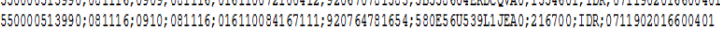

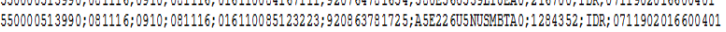

Sumber: KPPN Khusus Penerimaan

Pelaksana seksi rekonsiliasi menyandingkan data transaksi dan pelimpahan dari bank/pos persepsi pada portal rekonsiliasi MPN G2 dengan data settlement setelah pukul 15.00 WIB. Dari proses tersebut, pelaksana seksi rekonsiliasi memperoleh hasil rekonsiliasi dari portal rekonsiliasi MPN G2.

Portal rekonsiliasi MPN G2 merupakan salah satu alat kerja utama dalam proses bisnis pelaksanaan rekonsiliasi, baik rekonsiliasi transaksi maupun rekonsiliasi kas. Portal rekonsiliasi berperan penting dalam mengolah data transaksi yang disampaikan oleh bank/pos persepsi untuk disandingkan dengan data yang tercatat pada sistem settlement.

Portal rekonsiliasi juga menghasilkan dan menyajikan hasil rekonsiliasi transaksi dan rekonsiliasi kas. Terdapat 4 kriteria data hasil rekonsiliasi transaksi dalam portal rekonsiliasi MPN G2, yaitu match, CA Only, Settlement Only, dan failed yang ditunjukkan pada gambar 4.

Gambar 4

Hasil Rekonsiliasi Transaksi

Pada Portal Rekonsiliasi MPN G2

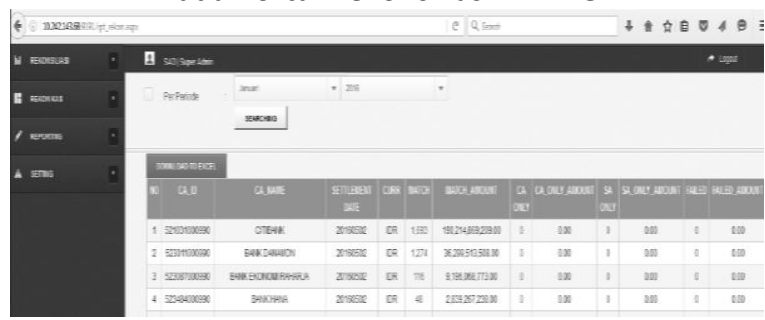

Sumber: KPPN Khusus Penerimaan

Match adalah status dari hasil rekonsiliasi melalui portal rekonsiliasi MPN G2 yang menunjukkan bahwa data transaksi penerimaan negara yang telah disampaikan oleh bank/pos persepsi dengan data yang tercatat pada sistem settlement. Match merupakan data yang termasuk dalam kategori data settled.

Match menunjukkan bahwa tidak ada perbedaan data maupun selisih antara data yang tercatat pada bank/pos persepsi dan data yang tercatat pada sistem settlement. Jumlah Penerimaan Negara yang telah dilimpahkan oleh bank/pos persepsi ke rekening KUN sesuai dengan jumlah yang tercatat pada sistem settlement.

CA Only yang merupakan singkatan dari Collecting Agent Only adalah status dari hasil rekonsiliasi melalui portal rekonsiliasi MPN G2 yang menunjukkan bahwa penerimaan negara yang catatan transaksi dan uangnya berada di Bank/Pos Persepsi. Bank/pos persepsi mencatat data transaksi Penerimaan Negara, namun data transaksi Penerimaan Negara tersebut tidak tercatat pada sistem settlement.

Hal ini menunjukkan adanya suatu perbedaan data transaksi Penerimaan Negara antara bank/pos persepsi dan sistem settlement. Jumlah Penerimaan Negara yang telah dilimpahkan oleh bank/pos persepsi ke rekening KUN tidak sesuai dengan jumlah yang tercatat pada sistem settlement. Transaksi dengan status CA Only tidak mendapatkan NTPN.

CA Only terjadi karena terputusnya koneksi pada saat bank/pos persepsi melakukan inquiry dan payment ke sistem settlement untuk memperoleh NTPN. Terputusnya koneksi tersebut menyebabkan sistem settlement tidak mencatat data transaksi tersebut. Hal ini mengakibatkan sistem settlement tidak menerbitkan NTPN. Ketika koneksi putus, secara manual sistem akan mencoba sampai tiga kali selama 25 detik. Apabila tidak berhasil maka bank/pos persepsi akan memberikan BPN sementara. BPN sementara tersebut disebut juga BPN tanpa teraan NTPN.

SA Only yang merupakan singkatan dari Settlement Only adalah status dari hasil rekonsiliasi melalui portal rekonsiliasi MPN G2 yang menunjukkan bahwa transaksi penerimaan negara yang tercatat pada sistem Settlement, namun tidak terdapat pada data penerimaan negara yang telah disampaikan oleh bank/pos persepsi.

Berbeda dengan CA Only yang belum mendapatkan NTPN, data transaksi SA Only telah mendapatkan NTPN dari sistem settlement. Dalam kondisi ini, terdapat perbedaan antara data transaksi penerimaan Negara pada bank/pos persepsi dan data transaksi penerimaan Negara pada sistem settlement. Jumlah penerimaan Negara yang telah dilimpahkan oleh bank/pos persepsi ke rekening KUN tidak sesuai dengan jumlah yang tercatat pada sistem settlement.

SA Only terjadi karena putusnya koneksi ketika sistem settlement akan menyampaikan NTPN (generate NTPN) kepada Bank/pos persepsi. Sistem settlement telah menerbitkan NTPN untuk data transaksi tersebut, namun Bank/pos persepsi belum menerima. Akibatnya, bank/pos persepsi tidak memasukkan data transaksi tersebut ke dalam DNP Elektronik dan tidak melimpahkan penerimaan Negara tersebut ke rekening KUN.

Failed adalah status dari hasil rekonsiliasi melalui portal rekonsiliasi MPN G2 yang menunjukkan bahwa terdapat data transaksi yang disampaikan oleh bank/pos persepsi tidak valid. Hal ini menyebabkan ketidaksesuaian data transaksi Penerimaan Negara antara bank/pos persepsi dengan sistem settlement. Dalam kondisi ini hasil rekonsiliasi menunjukkan bahwa terdapat perbedaan data transaksi antara bank/pos persepsi dan sistem settlement. Data dengan status failed biasanya disebabkan oleh perbedaan cut off waktu antara bank/pos persepsi dan sistem settlement. 
Dari rekapitulasi hasil rekonsiliasi yaitu rekonsiliasi transaksi dan rekonsiliasi kas tersebut, pelaksana seksi rekonsiliasi menyusun Laporan Hasil Rekonsiliasi (LHR). Pelaksana seksi rekonsiliasi menyampaikan LHR kepada kepala seksi rekonsiliasi.

Selanjutnya, kepala seksi rekonsiliasi akan memeriksa, meneliti, dan memberi paraf LHR. LHR yang telah diberi paraf oleh kepala seksi rekonsiliasi, disampaikan kepada Kepala Kantor KPPN Khusus Penerimaan. Setelah LHR disampaikan, Kepala seksi rekonsiliasi menindaklanjuti data transaksi dengan status SA Only, CA Only, dan failed dan penyelesaian terkait kekurangan pelimpahan, dan perbaikan DNP Elektronik yang disampaikan kepada bank/pos persepsi.

Langkah penyelesaian untuk data dengan status CA Only adalah menerbitkan NTPN dari sistem settlement. Penerbitan NTPN terkait data CA Only dilakukan secara by sistem. Selanjutnya, KPPN Khusus Penerimaan menyampaikan NTPN tersebut kepada Bank/Pos Persepsi.

Selanjutnya, Bank/pos persepsi memiliki kewajiban untuk menyampaikan NTPN tersebut kepada WP/WB/WS. KPPN Khusus Penerimaan juga memerintahkan Bank/Pos Persepsi untuk segera melimpahkan ke rekening sub Rekening KUN Penerimaan dalam hal dana atas data CA Only belum dilimpahkan.

Penerimaan Negara dengan status CA Only yang tidak dilimpahkan oleh Bank/Pos Persepsi pada hari kerja berkenaan, diperhitungkan sebagai keterlambatan/kekurangan pelimpahan oleh Bank/Pos Persepsi.

Dalam hal terdapat data Settlement Only, langkah penyelesaian yang dilakukan oleh KPPN Khusus Penerimaan adalah menyampaikan NTPN kepada Bank/Pos Persepsi.

Bank/pos persepsi memiliki kewajiban untuk menyampaikan NTPN tersebut kepada WP/WB/WS baik melalui telepon, SMS, atau e-mail sesuai dengan kebijakan yang diambil oleh bank/pos persepsi. KPPN Khusus Penerimaan juga memerintahkan Bank/Pos Persepsi melakukan perbaikan LHP Elektronik dalam hal data Settlement Only tidak terdapat dalam LHP Elektronik yang dibuat oleh Bank/Pos Persepsi serta memerintahkan Bank/Pos Persepsi untuk melimpahkan ke rekening sub Rekening KUN Penerimaan dalam hal dana atas data Settlement Only belum dilimpahkan.

Penerimaan Negara dengan status $C A$ only yang tidak dilimpahkan oleh Bank/Pos Persepsi pada hari kerja berkenaan, diperhitungkan sebagai keterlambatan/kekurangan pelimpahan oleh Bank/Pos Persepsi. Umumnya pada kasus Settlement Only, bank/pos persepsi diminta untuk melakukan perbaikan DNP Elektronik.

Langkah penyelesaian yang dilakukan KPPN Khusus Penerimaan terkait data dengan status failed yaitu dengan melakukan investigasi terhadap data terkait bersangkutan. Investigasi tersebut dilakukan untuk mencari tahu penyebab perbedaan data transaksi penerimaan Negara antara bank/pos persepsi dengan sistem settlement. Data failed sebagian besar disebabkan oleh perbedaan cut off waktu antara bank/pos persepsi dengan sistem settlement.

Terkait dengan perbaikan DNP Elektronik, KPPN Khusus Penerimaan menyampaikan pemberitahuan atas ketidaksesuaian hasil rekonsiliasi data transaksi, ketidaksesuaian pelimpahan (kurang/lebih limpah), serta permintaan perbaikan DNP Elektronik kepada Bank/Pos Persepsi.

Bank/pos persepsi wajib melakukan perbaikan DNP Elektronik apabila hasil rekonsiliasi menunjukkan data unsettled (data yang tidak sesuai). Bank/pos persepsi juga memiliki kewajiban untuk mengirim kembali hasil perbaikan DNP Elektronik kepada KPPN Khusus Penerimaan. KPPN Khusus Penerimaan juga menyampaikan surat peringatan kepada bank/pos persepsi. Surat tersebut berisi keterangan kekurangan pelimpahan disertai denda yang harus segera disetorkan ke sub-rekening KUN.

\subsection{Pelaksanaan Rekonsiliasi Transaksi Pada MPN G2 Periode 2015 s.d. Triwulan 12017}

Pada prinsipnya, terdapat dua macam jenis data hasil rekonsiliasi transaksi yaitu settled dan unsettled. Match adalah jenis data yang termasuk dalam jenis data settled, sedangkan CA Only, SA Only, dan failed termasuk data unsettled.

Tabel 1

Rekapitulasi Hasil Rekonsiliasi Transaksi Tahun 2015 Mata Uang IDR

\begin{tabular}{|l|r|r|r|r|}
\hline Jenis Data & Transaksi & \multicolumn{1}{c|}{$\%$} & \multicolumn{1}{c|}{ Nominal } & \multicolumn{1}{c|}{$\%$} \\
\hline Match & $8,134,079$ & $87.54 \%$ & $221,567,979,842,423$ & $74.696 \%$ \\
\hline CA Only & 8,007 & $0,086 \%$ & $121,833,359,129$ & $0,041 \%$ \\
\hline SA Only & 3,640 & $0,039 \%$ & $1,150,097,614,782$ & $0,388 \%$ \\
\hline Failed & 1,019 & $0,011 \%$ & $108,486,790,459$ & $0.037 \%$ \\
\hline
\end{tabular}

Sumber: KPPN Khusus Penerimaan, data diolah

Pada tahun 2015, data dengan kategori match mencapai $87,540 \%$ dari total data setelmen. Hal ini menunjukkan bahwa data settled (yang sesuai) memiliki jumlah yang lebih besar daripada data unsettled (yang tidak sesuai). Nilai transaksi data match memiliki persentase sebanyak $74,696 \%$ dari total nilai transaksi pada setelmen.

Ditinjau dari jumlah transaksinya, data transaksi dengan kategori CA Only memiliki jumlah transaksi paling besar di antara data transaksi unsettled lainnya yaitu sebesar 0,086\%, melebihi SA Only yang memiliki jumlah transaksi 0,039\% dan data failed yang memiliki jumlah transaksi 0,011\%. Namun, dari segi nilai transaksi ,SA Only memiliki nilai transaksi paling besar di antara data transaksi unsettled yaitu sebesar $0,388 \%$. CA Only dengan nilai sebesar $0,041 \%$ dari nilai setelmen dan data failed memiliki nilai transaksi paling kecil yaitu sebesar $0,037 \%$.

\section{Tabel 2}

Rekapitulasi Hasil Rekonsiliasi Transaksi Tahun 2016 Mata Uang IDR

\begin{tabular}{|l|r|r|r|r|}
\hline Jenis Data & \multicolumn{1}{|c|}{ Transaksi } & \multicolumn{1}{c|}{$\%$} & \multicolumn{1}{c|}{ Nominal } & \multicolumn{1}{c|}{$\%$} \\
\hline Match & $54,147,659$ & $99.85 \%$ & $1,345,083,391,422,820$ & $99.87 \%$ \\
\hline CA Only & 8,914 & $0,016 \%$ & $315,099,085,328$ & $0,023 \%$ \\
\hline SA Only & 55,005 & $0,101 \%$ & $1,298,277,903,296$ & $0,096 \%$ \\
\hline Failed & 8,099 & $0,015 \%$ & $114,236,142,170$ & $0.01 \%$ \\
\hline
\end{tabular}


Sumber: KPPN Khusus Penerimaan, data diolah

Pada tahun 2016, data dengan kategori match mengalami peningkatan menjadi 99,847\%dari total data setelmen. Hal ini menunjukkan bahwa data settled (yang sesuai) memiliki jumlah yang lebih besar daripada data unsettled (yang tidak sesuai). Nilai transaksi data match memiliki persentase sebanyak 99,865\% dari total nilai transaksi pada setelmen.

Ditinjau dari jumlah transaksinya, data transaksi dengan kategori SA Only memiliki jumlah transaksi paling besar di antara data transaksi unsettled lainnya yaitu sebesar $0,101 \%$, melebihi $C A$ Only yang memiliki jumlah transaksi 0,016\% dan data failed yang memiliki jumlah transaksi 0,016\%. Dari segi nilai transaksi, SA Only memiliki nilai transaksi paling besar di antara data transaksi unsettled yaitu sebesar 0,096\%. CA Only dengan nilai sebesar $0,023 \%$ dari nilai setelmen dan data failed memiliki nilai transaksi paling kecil yaitu sebesar $0,008 \%$.

Tabel 3

Rekapitulasi Hasil Rekonsiliasi Transaksi Triwulan I Tahun 2015 Mata Uang IDR

\begin{tabular}{|l|r|r|r|r|}
\hline Jenis Data & \multicolumn{1}{|c|}{ Transaksi } & \multicolumn{1}{c|}{$\%$} & \multicolumn{1}{c|}{ Nominal } & $\%$ \\
\hline Match & $19,226,131$ & $99.93 \%$ & $302,098,960,056,963$ & $99.96 \%$ \\
\hline CA Only & 2,640 & $0,014 \%$ & $48,582,987,710$ & $0,023 \%$ \\
\hline SA Only & 10,231 & $0,053 \%$ & $39,651,168,344$ & $0,096 \%$ \\
\hline Failed & 304 & $0,002 \%$ & $1,757,580,502$ & $0.01 \%$ \\
\hline
\end{tabular}

Sumber: KPPN Khusus Penerimaan, data diolah

Pada triwulan I tahun 2017, data dengan kategori match mengalami peningkatan menjadi 99,927\%dari total data setelmen. Hal ini menunjukkan bahwa data settled (yang sesuai) memiliki jumlah yang lebih besar daripada data unsettled (yang tidak sesuai). Nilai transaksi data match memiliki persentase sebanyak 99,967\% dari total nilai transaksi pada setelmen.

Ditinjau dari jumlah transaksinya, data transaksi dengan kategori SA Only memiliki jumlah transaksi paling besar di antara data transaksi unsettled lainnya yaitu sebesar $0,053 \%$, melebihi $C A$ Only yang memiliki jumlah transaksi 0,014\% dan data failed yang memiliki jumlah transaksi 0,002\%. Dari segi nilai transaksi, $S A$ Only memiliki nilai transaksi paling besar di antara data transaksi unsettled yaitu sebesar 0,096\%. CA Only dengan nilai sebesar $0,023 \%$ dari nilai setelmen dan data failed memiliki nilai transaksi paling kecil yaitu sebesar $0,008 \%$.

Tabel 4

Rekapitulasi Hasil Rekonsiliasi Transaksi Tahun 2015 Mata Uang USD

\begin{tabular}{|l|r|r|r|r|}
\hline Jenis Data & Transaksi & \multicolumn{1}{c|}{$\%$} & Nominal & $\%$ \\
\hline Match & 6,472 & $66.31 \%$ & $3,024,384,645$ & $94.34 \%$ \\
\hline CA Only & 4 & $0,0410 \%$ & 124,639 & $0,0039 \%$ \\
\hline SA Only & 2 & $0,0205 \%$ & 3,662 & $0,0001 \%$ \\
\hline Failed & 1 & $0,0102 \%$ & 3,661 & $0,0001 \%$ \\
\hline
\end{tabular}

Sumber: KPPN Khusus Penerimaan, data diolah

Pada tahun 2015, data dengan kategori match hanya mencapai $66,3115 \%$ dari total data setelmen. Hal ini menunjukkan bahwa data settled (yang sesuai) memiliki jumlah yang lebih besar daripada data unsettled (yang tidak sesuai). Nilai transaksi data match memiliki persentase sebanyak 94,3387\% dari total nilai transaksi pada setelmen.

Ditinjau dari jumlah transaksinya, data transaksi dengan kategori CA Only memiliki jumlah transaksi paling besar diantara data transaksi unsettled lainnya yaitu sebesar $0,041 \%$, melebihi $S A$ Only yang memiliki jumlah transaksi 0,0205\%dan data failed yang memiliki jumlah transaksi 0,0102\%. Dari segi nilai transaksi, $C A$ Only juga memiliki nilai transaksi paling besar di antara data transaksi unsettled yaitu sebesar 0,0039\%. SA Only dan data failed dengan nilai transaksi sebesar $0,0001 \%$.

Tabel 5

Rekapitulasi Hasil Rekonsiliasi Transaksi Tahun 2016 Mata Uang USD

\begin{tabular}{|l|r|c|c|r|}
\hline Jenis Data & Transaksi & \multicolumn{1}{c|}{$\%$} & Nominal & \multicolumn{1}{c|}{$\%$} \\
\hline Match & 73,154 & $99.91 \%$ & $5,873,682,015$ & $99.89 \%$ \\
\hline CA Only & 11 & $0,0150 \%$ & 204,108 & $0,0035 \%$ \\
\hline SA Only & 18 & $0,0246 \%$ & 780,567 & $0,0133 \%$ \\
\hline Failed & 5 & $0,0068 \%$ & $3,980,501$ & $0.07 \%$ \\
\hline
\end{tabular}

Sumber: KPPN Khusus Penerimaan, data diolah

Pada tahun 2016, data dengan kategori match meningkat hingga mencapai 99,9140\% dari total data setelmen. Hal ini menunjukkan bahwa data settled (yang sesuai) memiliki jumlah yang lebih besar daripada data unsettled (yang tidak sesuai). Nilai transaksi data match memiliki persentase sebanyak $99,8911 \% \%$ dari total nilai transaksi pada setelmen.

Berbeda dari tahun 2015, ditinjau dari jumlah transaksinya, data transaksi dengan kategori SA Only memiliki jumlah transaksi paling besar di antara data transaksi unsettled lainnya yaitu sebesar 0,0246\%, melebihi CA Only yang memiliki jumlah transaksi $0,0150 \%$ dan data failed yang memiliki jumlah transaksi $0,0068 \%$. Namun, dari segi nilai transaksi, data failed memiliki nilai transaksi paling besar di antara data transaksi unsettled yaitu sebesar $0.0677 \%$. CA Only memiliki nilai transaksi sebesar $0,0035 \%$ dan $S A$ Only memiliki nilai transaksi sebesar 0,0133\% dari nilai setelmen.

Tabel III.6

Rekapitulasi Hasil Rekonsiliasi Transaksi Triwulan I Tahun 2017 Mata Uang USD

\begin{tabular}{|l|r|c|c|c|}
\hline Jenis Data & Transaksi & $\%$ & Nominal & $\%$ \\
\hline Match & 33,131 & $99.964 \%$ & $2,117,126,144$ & $99.996 \%$ \\
\hline CA Only & 5 & $0,0151 \%$ & 6,866 & $0,0003 \%$ \\
\hline SA Only & 8 & $0,0241 \%$ & 81,743 & $0,0039 \%$ \\
\hline Failed & - & $0,0000 \%$ & & $0.000 \%$ \\
\hline
\end{tabular}

Sumber: KPPN Khusus Penerimaan, data diolah

Pada triwulan I tahun 2016, data dengan kategori match meningkat menjadi 99,9638\% dari total data setelmen. Hal ini menunjukkan bahwa data settled (yang sesuai) memiliki jumlah yang lebih besar daripada data unsettled (yang tidak sesuai). Nilai transaksi data match memiliki persentase sebanyak $99,8911 \% \%$ dari total nilai transaksi pada setelmen.

Serupa dengan tahun 2016, ditinjau dari jumlah transaksinya, data transaksi dengan kategori SA Only memiliki jumlah transaksi paling besar di antara data transaksi unsettled lainnya yaitu sebesar 0,0241\%, 
melebihi CA Only yang memiliki jumlah transaksi $0,0151 \%$ dan data failed yang memiliki jumlah transaksi $0 \%$. Dari segi nilai transaksi , SA Only juga memiliki nilai transaksi paling besar di antara data transaksi unsettled yaitu sebesar 0,0039\%. CA Only memiliki nilai transaksi sebesar $0,0003 \% \%$ dan data failed yang tidak memiliki nilai transaksi.

\section{Gambar 4}

Perkembangan Data Unsettled dalam Mata Uang IDR

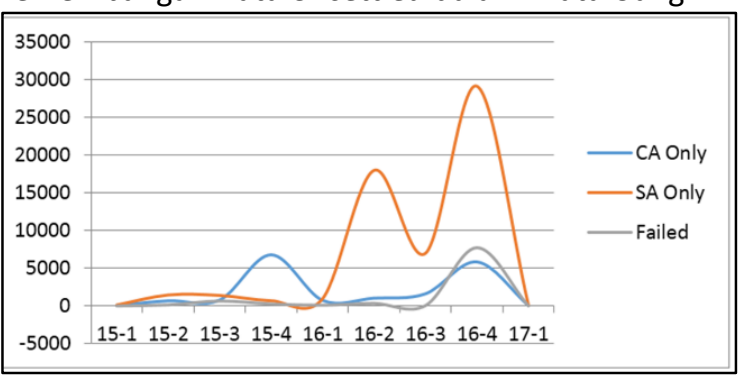

Sumber: KPPN Khusus Penerimaan, data diolah

Perkembangan data unsettled dalam mata uang Rupiah. CA Only memiliki jumlah transaksi paling besar pada tahun 2015 triwulan IV dan pada tahun 2017 triwulan I tidak ada transaksi dengan kriteria CA Only. SA Only memiliki jumlah transaksi paling besar pada tahun 2016 triwulan IV dan memiliki jumlah transaksi paling kecil pada tahun tahun 2017 triwulan I. Data failed memiliki jumlah transaksi paling besar pada tahun 2016 triwulan IV. Pada tahun 2015 triwulan I dan tahun 2017 triwulan I, tidak ada transaksi dengan kriteria failed.

\section{Gambar 5}

Perkembangan Data Unsettled dalam Mata Uang USD

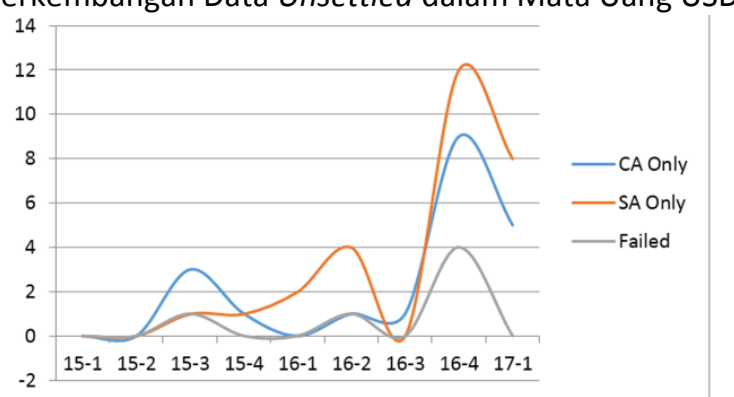

Sumber: KPPN Khusus Penerimaan, data diolah

Perkembangan data unsettled dalam mata uang asing. CA Only memiliki jumlah transaksi paling besar pada tahun 2016 triwulan IV. Pada tahun 2015 triwulan I dan II serta tahun 2016 triwulan I tidak ada transaksi dengan kriteria CA Only. SA Only memiliki jumlah transaksi paling besar pada tahun 2016 triwulan IV.

Pada tahun 2015 triwulan I dan II serta tahun 2016 triwulan III tidak ada transaksi dengan kriteria SA Only. Data failed memiliki jumlah transaksi paling besar pada tahun 2016 triwulan IV. Dalam 9 triwulan terakhir, terdapat 6 triwulan dimana tidak ada transaksi dengan kriteria data failed.

Berdasarkan data LKPP Tahun 2009 dan 2010, pengelolaan MPN memperoleh opini disclaimer dari BPK. Alasan opini disclaimer tersebut karena BPK menganggap data transaksi unmatch di dalam sistem MPN G1 sebagai data yang bermasalah dan berpotensi merugikan negara yaitu reversal, tidak diakui, MPN unmatch, cancel out match, dan LKP unmatch.
Pada saat itu, Ditjen Perbendaharaan khususnya Sub Direktorat Penerimaan Negara memiliki peran yang sangat penting dalam menyelesaikan masalah tersebut. Untuk menjaga akuntabilitas data transaksi MPN terutama yang bermasalah atau unmatch, Sub Direktorat Penerimaan Negara setiap 1-2 bulan sekali mengadakan klarifikasi hasil rekonsiliasi antara Ditjen Perbendaharaan dan Bank/Pos Persepsi.

Kegiatan ini bertujuan untuk mencocokkan data yang telah direkonsiliasi lewat sistem MPN, baik di pihak Ditjen Perbendaharaan maupun yang ada di pihak Bank/Pos Persepsi. Dengan diadakannya kegiatan tersebut, data MPN yang bermasalah dan berpotensi merugikan negara menjadi dapat dipertanggungjawabkan akuntabilitasnya sehingga diharapkan nantinya hasil audit BPK memperoleh opini Wajar Tanpa Pengecualian (WTP).

Pada tahun 2011, hasil audit BPK terhadap Laporan Keuangan Pemerintah Pusat tahun 2010 telah menghasilkan opini Wajar Tanpa Pengecualian (WTP). Opini Wajar Tanpa Pengecualian (WTP) tersebut masih dapat dipertahankan hingga tahun berikutnya yaitu tahun 2012 atau terhadap Laporan Keuangan Pemerintah Pusat tahun 2011. Hasil audit BPK terhadap pengelolaan penerimaan melalui sistem MPN setiap tahunnya terus meningkat.

Dengan adanya MPN G2, dimana rekonsiliasi dilakukan secara harian dan penyelesaian atas data unsettled secara by sistem sehingga pada pada $\mathrm{H}+1$ semua data transaksi adalah data settled. Meskipun pada tahun 2015, MPN G2 memperoleh opini BPK Wajar Dengan Pengecualian (WDP), tetapi pada tahun 2016, MPN G2 kembali mendapatkan opini BPK Wajar Tanpa Pengecualian (WTP).

\subsection{Permasalahan Rekonsiliasi Transaksi Pada MPN G2}

Dalam melaksanakan rekonsiliasi terdapat beberapa permasalahan yang terjadi dan menyebabkan terhambatnya proses rekonsiliasi transaksi hingga menjadi penyebab data unsettled. Permasalahan yang terjadi pada pelaksanaan rekonsiliasi transaksi meliputi :

a. Jenis Data yang Dihasilkan Rekonsiliasi Transaksi

Pada Gambar 4 terkait hasil rekonsiliasi transaksi melalui portal rekonsiliasi MPN G2, menunjukkan bahwa ID bank/pos persepsi, nama bank/pos persepsi, tanggal rekonsiliasi, mata uang yang digunakan, jumlah transaksi dan jumlah penerimaan negara yang dilimpahkan berkriteria Match, SA only, CA only, dan Failed.

Portal rekonsiliasi terkait rekonsiliasi transaksi akan menghasilkan empat jenis data dengan kriteria Match, SA only, CA only, dan Failed. Hal ini tidak sesuai dengan ketentuan jenis data yang tercantum dalam PMK Nomor 32/PMK.05/2014 tentang Sistem Penerimaan Negara Secara Elektronik.

Sesuai dengan PMK Nomor 32/PMK.05/2014 tentang Sistem Penerimaan Negara Secara Elektronik, rekonsiliasi transaksi hanya menghasilkan tiga jenis data yaitu kesesuaian data (settled), CA Only dan Settlement only. Menurut peraturan, Failed tidak 
termasuk dalam jenis data yang dihasilkan dari rekonsiliasi transaksi. Portal rekonsiliasi memang mengalami perkembangan sesuai kebutuhan. Namun, perlu diperhatikan bahwa portal rekonsiliasi harus berpedoman pada ketentuan-ketentuan yang telah ditetapkan oleh peraturan perundang-undangan.

b. Status Terakhir Data Transaksi Unsettled

Hasil rekonsiliasi transaksi pada dasarnya menghasilkan dua jenis data yaitu settled dan unsettled. Jenis data hasil rekonsiliasi yang termasuk data unsettled adalah CA Only, SA Only, dan Failed.

Penyelesaian ketiga jenis data hasil rekonsiliasi tersebut dilakukan by sistem melalui portal rekonsiliasi dengan menerbitkan dan menyampaikan NTPN serta pemberian surat teguran kurang/lebih limpah kepada bank/pos persepsi. Klarifikasi hasil rekonsiliasi transaksi berupa data unsettled diselesaikan dalam waktu maksimal $\mathrm{H}+1$ sehingga pada waktu $\mathrm{H}+1$ hasil rekonsiliasi transaksi menunjukkan semua data transaksi adalah data transaksi settled (data transaksi yang sesuai). Dengan demikian tidak ada lagi data transaksi dengan status CA Only, SA Only maupun Failed.

Namun, hal itu tidak seperti yang terlihat pada portal rekonsiliasi. Pada portal rekonsiliasi, tidak ada penanda ataupun keterangan bahwa data transaksi unsettled telah diselesaikan atau belum diselesaikan. Status dari data unsettled masih tetap dan tidak berubah. Tidak ada keterangan bahwa NTPN telah diterbitkan oleh sistem settlement dan telah disampaikan kepada bank/pos perpepsi.

$\mathrm{Hal}$ ini dikhawatirkan akan menimbulkan penafsiran yang negatif dari pihak eksternal ynag tidak mengetahui bahwa sebenarnya data transaksi tersebut telah clear dan telah dilakukan penyelesaian.

\section{c. Timed Out}

Timed out atau putusnya koneksi saat terjadi proses pencatatan penerimaan Negara melalui sistem MPN G2. Kesalahan ini merupakan penyebab utama terjadinya data unsettled yaitu jenis data yang tidak sesuai. Kesalahan ini terjadi karena gagalnya koneksi atau putusnya hubungan antara sistem MPN yang ada di Bank/Pos Persepsi dengan sistem settlement MPN $\mathrm{G} 2$.

Timed out dapat terjadi pada 3 sistem

1) Timed out pada biller

2) Timed out pada bank/pos persepsi

3) Timed out pada sistem settlement

Koneksi yang terputus dalam proses pengiriman data di dalam sistem MPN G2, mengakibatkan tidak dapat diterimanya NTPN di Bank/Pos Persepsi. Hal inilah yang mengakibatkan terjadinya data $C A$ Only dan SA Only.

d. Gangguan jaringan

Gangguan jaringan dalam pengelolaan penerimaan negara secara elektronik. Gangguan jaringan ini dapat menyebabkan terkendalanya pelaksanaan rekonsiliasi transaksi dan mempengaruhi hasil dari rekonsiliasi transaksi. Gangguan-gangguan tersebut meliputi antara lain.

1) gangguan yang menyebabkan Biller tidak dapat menerbitkan Kode Billing.
2) gangguan yang menyebabkan Bank/Pos Persepsi tidak dapat menerima informasi data setoran atas Kode Billing dari sistem Settlement;

3) gangguan yang menyebabkan Bank/Pos Persepsi tidak dapat menerima NTPN setelah melakukan perintah bayar atas transaksi Penerimaan Negara; dan

4) gangguan yang mengakibatkan terganggunya proses pelimpahan Penerimaan Negara dan/atau penyampaian LHP Elektronik kepada KPPN Khusus Penerimaan sesuai dengan ketentuan.

e. Human Error

Meskipun rekonsiliasi MPN G2 dilakukan secara elektronik dan berbasis teknologi informasi, namun tidak dipungkiri bahwa sebelum proses rekonsiliasi terdapat penatausahaan penerimaan negara yang dilakukan oleh SDM. Misalnya, petugas bank/pos persepsi merekapitulasi kembali jumlah penerimaan negara, meng-input data untuk menghasilkan LHP Elektronik, DNP Elektronik, dan rekening koran elektronik ataupun meng-upload data tersebut ke Portal Rekonsiliasi MPN G2.

Penyelenggaraan layanan Penerimaan Negara di bank/pos persepsi merupakan salah satu dari banyak bentuk layanan yang diberikan oleh bank/pos persepsi. Kurangnya kompetensi SDM dalam melakukan handling atas pekerjaan tersebut menjadikan celah adanya human error pada pelaksanaan Penerimaan Negara.

Bank/pos persepsi menyelenggaraan Penerimaan Negara di wilayah pusat dan juga daerah. Hal ini dapat menambah frekuensi adanya human error apabila petugas bank/pos persepsi belum paham karena kurangnya sosialisasi terkait aktivitas penyelenggaraan Penerimaan Negara.

Selain bank/pos persepsi, human error dapat berasal dari WP/WB/WS. Human error yang disebabkan WP/WB/WS sebagian besar dilakukan ketika proses perekaman data dan penerbitan billing. WP/WB/WS bertanggung jawab atas kelengkapan dan kebenaran data pembayaran. Contoh human error yang disebabkan oleh WP/WB/WS antara lain adalah salah input jumlah yang harus dibayarkan, salah memilih jenis pajak yang akan dibayar, testing, dan lain-lain

\subsection{Penyelesaian Permasalahan Rekonsiliasi Transaksi Pada MPN G2}

a. Sumber daya manusia

Sumber daya manusia memiliki peran penting dalam penyelenggaraan rekonsiliasi transaksi atas Penerimaan Negara melalui MPN G2. Sumber daya manusia yang mempengaruhi penyelenggaraan rekonsiliasi transaksi adalah WP/WB/WS, petugas bank/pos persepsi, dan pegawai KPPN Khusus Penerimaan. Sumber daya manusia masih berperan penting dalam menjaga validitas dan keakuratan Penerimaan Negara.

Sumber daya manusia yang pertama adalah WP/WB/WS. Kesalahan yang diakibatkan oleh WP/WB/WS dapat dikategorikan sebagai human error. WP/WB/WS berperan penting ketika melakukan 
perekaman data dan pada saat pembuatan billing. WP/WB/WS melakukan perekaman data maupun pembuatan billing secara mandiri. WP/WB/WS juga bertanggung jawab atas kelengkapan dan kebenaran data pembayaran.

Perlu dilakukan upaya sosialisasi ataupun kampanye baik secara formal maupun informal terkait pentingnya kelengkapan dan kebenaran data yang disampaikan oleh WP/WB/WS ketika melakukan perekaman data dan pembuatan billing. Dengan upaya-upaya yang dilakukan, diharapkan WP/WB/WS memiliki pengetahuan dan lebih memahami pelaksanaan Penerimaan Negara.

Petugas bank/pos persepsi memiliki peran penting dalam pelaksanaaan rekonsiliasi transaksi. Petugas bank/pos persepsi menyusun laporan-laporan terkait data transaksi yang nantinya akan disampaikan kepada KPPN Khusus Penerimaan.

Selain itu, bank/pos persepsi juga berperan dalam mengkonfirmasikan data pembayaran WP/WB/WS apakah telah sesuai atau tidak. Pemahaman dan ketelitian petugas bank/pos persepsi diperlukan dalam menyusun laporan data transaksi tersebut. Kelalaian dari petugas bank/pos persepsi dapat mempengaruhi adanya data unsettled. Perlu adanya suatu pengarahan dan pengawasan rutin terhadap kinerja petugas bank/pos persepsi dalam penyelenggaraan Penerimaan Negara.

Selanjutnya, jika dilihat dari segi jumlah dan proporsi pegawai KPPN Khusus Penerimaan, dapat dikatakan bahwa dengan jumlah 29 pegawai, KPPN Khusus Penerimaan mampu melaksanakan tugas dan fungsinya. Jumlah tersebut dianggap cukup memadai.

Dari segi kompetensi, pegawai KPPN Khusus Penerimaan sudah menunjukkan kinerja yang positif, tetapi hal ini tidak serta merta menjadikan KPPN Khusus Penerimaan tidak berbenah diri. Kompetensi pegawai KPPN Khusus Penerimaan tetap perlu dikembangkan. Hal ini dilakukan mengingat perkembangan teknologi yang lebih cepat dari birokrasi.

Selain itu, KPPN Khusus Penerimaan tertarik dengan salah satu struktur organisasi Kantor Pelayanan Pajak yaitu Account Representative (AR) yang ada pada Direktorat Jenderal Pajak (DJP). Dalam KMK Nomor 98/KMK.01/2006 tentang Account Representative pada Kantor Pelayanan Pajak yang Telah Mengimplementasikan Organisasi Modern, Account Representative (AR) adalah pegawai yang diangkat pada setiap Seksi Pengawasan dan Konsultasi di KPP yang mengimplementasikan Organisasi Modern. Tugas AR pada KPP antara lain melakukan pengawasan kepatuhan, memberikan konsultasi/ bimbingan, menyusun profil, menganalisis kinerja, dan melakukan rekonsiliasi data dari WP.

Konsep Account Representative ini dapat diadopsi oleh KPPN Khusus Penerimaan dalam rangka pengawasan terhadap kepatuhan bank/pos persepsi dalam menyelenggarakan penerimaan Negara. Pegawai AR melakukan pengawasan dan memberi arahan serta konsultasi terhadap bank/pos persepsi yang dipegangnya. Satu pegawai AR dapat memegang
4 s.d. 6 bank/pos persepsi sehingga perkembangan bank/pos persepsi dapat termonitor dengan jelas dan berkesinambungan. Dengan adanya pengawasan yang lebih intens, diharapkan data unsettled karena kelalaian SDM dapat diminimalkan jumlah dan nilainya.

b. Kesiapan Berbagai Pihak

Sistem MPN G2 merupakan sistem terintegrasi dimana banyak pihak yang terkait dalam pelaksanaannya. Mulai dari sistem biller, sistem pada bank/pos persepsi, hingga sistem yang ada pada KPPN Khusus Penerimaan. Sistem biller telah menjadi tanggung jawab dari masing-masing biller yaitu DJP, DJBC, dan DJA.

Sistem pada bank/pos persepsi dikembangkan oleh bank/pos persepsi itu sendiri. Bank/pos persepsi dapat mengembangkan sistemnya sedemikian rupa, dengan catatan sistem tersebut terhubung dengan sistem MPN G2. Sistem yang ada pada KPPN Khusus Penerimaan dibuat dan dikembangkan oleh Direktorat Sistem Informasi dan Teknologi Perbendaharaan (Direktorat SITP).

Secara prinsip, KPPN Khusus Penerimaan adalah user (pengguna) dari portal rekonsiliasi MPN G2. KPPN Khusus Penerimaan tidak merancang dan membuat portal rekonsiliasi tersebut. Ketika terjadi kasus seperti itu, KPPN Khusus Penerimaan mengevaluasi dan mengupayakan untuk menyampaikan hasil evaluasi tersebut kepada Direktorat SITP.

Hasil evaluasi memuat apa saja yang kurang dan apa saja yang perlu ditambah terkait pelaksanaan Penerimaan Negara. KPPN Khusus Penerimaan telah menyampaikan hasil evaluasi terkait permasalahan yang ada kepada Direktorat SITP. Kesiapan dari seluruh pihak dapat mendorong meningkatnya data settled dan berkurangnya data unsettled.

c. Peningkatan dan Penguatan Jaringan Informasi dan Komunikasi di Seluruh Wilayah Indonesia

Perlu peningkatan dan penguatan jaringan informasi dan komunikasi baik dalam jumlahnya maupun kapasitasnya sehingga jaringan MPN G2 dapat menjangkau seluruh wilayah Indonesia tanpa terkecuali. Adanya peningkatan dan penguatan jaringan informasi dan komunikasi ini juga diharapkan dapat meminimalkan adanya gangguan-gangguan pada sistem. Adanya peningkatan dan penguatan juga diharapkan mampu membuat hasil rekonsiliasi transaksi minim data unsettled.

Selain itu, perlu juga adanya suatu pemeriksaan dan pengawasan rutin untuk memantau dan memastikan berfungsinya jaringan tersebut. Hal ini untuk memastikan agar dalam pelaksanaan Penerimaan Negara, jaringan dalam kondisi yang mumpuni dan kompatibel.

d. Penyempurnaan sistem rekonsiliasi transaksi pada portal rekonsiliasi MPN G2

Rekonsiliasi transaksi merupakan salah satu proses bisnis dalam pelaksanaan penerimaan Negara. Pelaksanaan rekonsiliasi transaksi dilaksanakan by sistem. Seperti yang kita ketahui, masih terdapat beberapa hal pada portal rekonsiliasi MPN G2 yang belum sesuai dengan ketentuan perundang-undangan. Perlu dilakukan suatu penyempurnaan agar Portal 
Rekonsiliasi MPN G2 menyelenggarakan rekonsiliasi transaksi secara mumpuni.

Jenis data dari hasil rekonsiliasi transaksi yang masih belum sesuai dengan PMK Nomor 32/PMK.05/2014 tentang Sistem Penerimaan Negara Secara Elektronik perlu dikaji lebih mendalam. Pada dasarnya, data failed ada karena kubutuhan pengklasifikasian salah satu hasil rekonsiliasi transaksi dimana terdapat data tidak valid yang disampaikan oleh bank/pos persepsi.

Data-data yang termasuk data failed dimana seharusnya data itu tidak termasuk dalam salah satu jenis data hasil rekonsiliasi transaksi, perlu ditinjau lebih jauh kriteria dan proses penyelesaian data dengan kasus seperti itu.

Status terakhir dari data unsettled pada portal rekonsiliasi juga menjadi fokus dari penyempurnaan sistem MPN G2. Status terakhir dari data unsettled harus disesuaikan dengan keadaaan sebenarnya apakah data tersebut telah dilakukan penyelesaian dan telah settled atau belum.

Portal rekonsiliasi MPN G2 hendaknya memfasilitasi perubahan status dari data-data unsettled. Fasilitas itu mencakup perubahan status data, checklist penerbitan NTPN dan penyampaian NTPN untuk data CA Only, checklist penyampaian NTPN untuk data SA Only, perbaikan DNP Elektronik dan lebih/kurang limpah. Dengan adanya semua fasilitas itu diharapkan tidak ada lagi penafsiran -penafsiran yang meragukan validitas dan keakuratan dari sistem Penerimaan Negara.

\section{KESIMPULAN DAN SARAN}

\subsection{Kesimpulan}

Rekonsiliasi transaksi melalui portal rekonsiliasi menghasilkan 4 jenis kriteria data, yaitu match, $C A$ Only, SA Only, dan Failed. Match menunjukkan bahwa data transaksi penerimaan negara yang telah disampaikan oleh bank/pos persepsi sesuai dengan data yang tercatat pada sistem settlement. CA Only menunjukkan bahwa penerimaan negara yang catatan transaksi dan uangnya berada di Bank/Pos Persepsi. SA Only menunjukkan bahwa transaksi penerimaan negara yang tercatat pada sistem Settlement, namun tidak terdapat pada data penerimaan negara yang telah disampaikan oleh bank/pos persepsi. Failed menunjukkan bahwa terdapat data transaksi yang disampaikan oleh bank/pos persepsi tidak valid.

Hasil rekonsiliasi transaksi periode Tahun 2015 s.d triwulan 1 Tahun 2017 menunjukkan bahwa data settled lebih besar dari data unsettled. Data settled meliputi data match, sedangkan data unsettled meliputi data CA Only, SA Only, dan failed. Jumlah data unsettled terbesar adalah SA Only, sedangkan jumlah data unsettled terkecil adalah failed. Opini BPK terhadap MPN G2 pada tahun 2015 adalah Wajar Dengan Pengecualian (WDP) dan pada tahun 2016 meningkat menjadi Wajar Tanpa Pengecualian (WDP).

Permasalahan terkait pelaksanaan rekonsiliasi transaksi meliputi jenis data yang dihasilkan rekonsiliasi transaksi melalui portal rekonsiliasi tidak sesuai dengan ketentuan dalam PMK Nomor 32/PMK.05/2014 tentang Sistem Penerimaan Negara Secara Elektronik, status terakhir data unsettled yang masih tetap dan tidak berubah walaupun sudah dilakukan penyelesaian, timed out pada sistem biller, sistem pada bank/pos persepsi, dan sistem settlement, gangguan jaringan, serta human error dari WP/WB/WS dan bank/pos persepsi.

\subsection{Saran}

a. Peningkatan kualitas SDM

Peningkatan kualitas SDM yang pertama meliputi peningkatan pengetahuan dan pemahaman terkait pentingnya kelengkapan dan kebenaran data pembayaran oleh WP/WB/WS. Peningkatan pengetahuan dan pemahaman kualitas WP/WB/WS dapat dilakukan melalui sosialisasi, kampanye, dan program-program edukasi lainnya. Kegiatan tersebut menekankan pada pentingnya peran WP/WB/WS dalam mempertanggungjawabkan data pembayaran sehingga meminimalkan adanya human error pada WP/WB/WS.

Peningkatan kualitas SDM yang kedua melalui peningkatan pemahaman, kesungguhan, komitmen, dan keahlian dari bank/pos persepsi. Pelaksanaan Penerimaan Negara merupakan salah satu dari beberapa bentuk layanan yang disediakan oleh bank/pos persepsi. Fokus dari bank/pos persepsi tidak hanya pada pelaksanaan Penerimaan Negara, padahal, bank/pos persepsi memiliki peran penting dalam pelaksanaan rekonsiliasi transaksi dalam rangka menjaga validitas dan keakuratan data transaksi. Perlu adanya suatu pengarahan dan pengawasan rutin terhadap kinerja petugas bank/pos persepsi dalam penyelenggaraan Penerimaan Negara.

Peningkatan kualitas SDM yang ketiga adalah melalui peningkatan kinerja KPPN Khusus Penerimaan dalam rangka pengawasan terhadap bank/pos persepsi. Secara jumlah, KPPN Khusus. KPPN Khusus Penerimaan diharapkan terus meningkatkan kompetensinya karena perkembangan teknologi yang sangat cepat namun perkembangan birokrasi cenderung lambat.

Selain itu, konsep Account Representative yang telah diimplementasikan pada KPP dapat diadopsi oleh KPPN Khusus Penerimaan dalam rangka pengawasan terhadap kepatuhan bank/pos persepsi dalam menyelenggarakan Penerimaan Negara. Dengan adanya konsep ini, KPPN Khusus Penerimaan diharapkan mampu meningkatkan pengawasan dan memberi arahan serta konsultasi terhadap bank/pos persepsi dengan lebih intens.

b. Kesiapan berbagai pihak

Sistem MPN G2 merupakan sistem terintegrasi dimana banyak pihak yang terkait dalam pelaksanaannya. Kesiapan dari pihak-pihak yang terkait turut mempengaruhi pelaksanaan sistem MPN G2, utamanya pelaksanaan rekonsiliasi transaksi. Pihakpihak yang terlibat dalam pelaksanaan MPN G2 meliputi biller, bank/pos persepsi, KPPN Khusus Penerimaan, dan Direktorat SITP. 
Pihak-pihak ini bertanggung jawab memastikan pelaksanaan MPN G2. Masing-masing pihak bertanggung jawab untuk mengembangkan sistemnya yang terhubung dengan sistem MPN. Mulai dari sistem biller, sistem pada bank/pos persepsi, hingga sistem yang ada pada KPPN Khusus Penerimaan.

c. Peningkatan dan penguatan jaringan informasi dan komunikasi

Peningkatan dan penguatan jaringan informasi dan komunikasi dalam jumlah dan kapasitas sehingga jaringan MPN G2 dapat menjangkau seluruh wilayah Indonesia tanpa terkecuali. Adanya peningkatan dan penguatan jaringan informasi dan komunikasi ini juga diharapkan dapat meminimalkan adanya gangguangangguan pada sistem. Adanya peningkatan dan penguatan juga diharapkan mampu membuat hasil rekonsiliasi transaksi minim dari data unsettled. Selain itu, perlu adanya suatu pemeriksaan dan pengawasan rutin untuk memantau dan memastikan berfungsinya jaringan tersebut. Hal ini untuk memastikan selama pelaksanaan Penerimaan Negara, jaringan dalam kondisi yang mumpuni dan kompatibel.

d. Penyempurnaan sistem rekonsiliasi transaksi pada portal rekonsiliasi MPN G2

Salah satu kendala pada pelaksanaan rekonsiliasi transaksi adalah masih terdapat beberapa hal pada portal rekonsiliasi MPN G2 yang belum sesuai dengan ketentuan perundang-undangan. Perlu dilakukan suatu penyempurnaan agar Portal Rekonsiliasi MPN G2 menyelenggarakan rekonsiliasi transaksi secara mumpuni. Penyempurnaan tersebut meliputi 2 hal, yaitu pada jenis data dari hasil rekonsiliasi transaksi yang masih belum sesuai dengan PMK Nomor 32/PMK.05/2014 tentang Sistem Penerimaan Negara Secara Elektronik dan status terakhir data unsettled yang telah diselesaikan.

\section{DAFTAR PUSTAKA}

Iskandar. 2017, Pemetaan Karakteristik Transaksi Time Out pada Sistem Penerimaan Negara Secara Elektronik dengan Data Mining, Pusat Penelitian dan Pengabdian kepada Masyarakat (P3M) Politeknik Keuangan Negara STAN.

Saroni dan Salamah, 2015. KPPN Khusus Penerimaan Koordinasi dan Sinergi - Kunci Sukses MPN G2, Majalah Treasury Indonesia Edisi 1 hal 18-20.

Sumantri, Joko.2017, Studi Pendahuluan Pengaruh Penerimaan dan Pengeluaran Negara Terhadap Imbal Hasil Mismatch Treasury Bills, Jurnal Pajak Indonesia, Edisi 1.

Cash Management Policies And Procedures Handbook. Revised: 9/2011

Ditjen PBN. (2014). Memahami Sistem Penerimaan Negara Melalui Modul MPN G2.

Mulyana, Budi. Penggunaan Akuntansi Akrual di Negara-Negara Lain: Tren di Negara-Negara Anggota OECD
Sigid Mulyadi. 2014. Modul Pokok Pokok Pengelolaan Kas Negara.

Modul Perencanaan Kas G-2

Manajemen DIPA Satker. Ditjen Perbendaharaan. 2010

Modul Cash Management. Eli Tamba \& Wibawa

Kementerian Keuangan dan World Bank Group. 2014. Reformasi Pengelolaan Kas di Indonesia: Dari Administrasi Kas Menuju Pengelolaan Kas Secara Aktif. Jakarta: Kementerian Keuangan dan World Bank Group.

Williams, M. (2004). Government cash management: good and bad practice. World Bank Technical Note.

Matthews, A., \& Cook, D. (2009). Capital Budgeting.

Slide Presentation: The Transactions Demand for Cash: An Inventory Theoretic Approach: William J. Baumol. Presented by Luoyi (Roy) Su. 2017. Cornell University. Ithaca, New York, USA

Modul Aplikasi Sistem Keuangan Desa Tatakelola (Siskeudes). Deputi Bidang Pengawasan Penyelenggaraan Keuangan, BPKP. 2016

Proses Bisnis Perbendaharaan Pada Modul Koneksitas Bendahara Umum Negara dengan Satker Selaku Pelaksana Pengguna Anggaran. Ditjen Perbendaharaan.2009

Pengendalian Uang Negara Melalui Penerapan Treasury Single Account. Priyono Dwi Nugroho.

Gardner, John. 2017. Presentation "Active Investment of Surplus Treasury Cash". IMF - FOTEGAL Workshop. Washington DC 17 February 2017

Bahan Presentasi Kementerian Keuangan, 2014. "Peraturan Sistem Perbendaharaan Dan Anggaran Negara"

Undang-Undang Republik Indonesia Nomor 17 Tahun 2003 tentang Keuangan Negara.

PMK Nomor 32/PMK.05/2014 tentang Sistem Penerimaan Negara Secara Elektronik. 